Article

\title{
Visualizing the Intellectual Structure and Evolution of Intelligent Transportation Systems: A Systematic Analysis of Research Themes and Trends
}

\author{
Nadia Karina Gamboa-Rosales ${ }^{1}$, José María Celaya-Padilla ${ }^{2}$ (D), \\ Ana Luisa Hernandez-Gutierrez ${ }^{2}$, Arturo Moreno-Baez ${ }^{2}$, Carlos E. Galván-Tejada ${ }^{2} \odot$, \\ Jorge I. Galván-Tejada ${ }^{2}$, Edgar González-Fernández ${ }^{3}$, , Hamurabi Gamboa-Rosales ${ }^{3, *(\mathbb{C}}$ \\ and José Ricardo López-Robles ${ }^{4}$ (1) \\ 1 Academic Unit of Electrical Engineering, CONACYT-Autonomous University of Zacatecas, Zacatecas 98000, \\ Mexico; ngamboa@conacyt.mx \\ 2 Academic Unit of Electrical Engineering, Autonomous University of Zacatecas, Zacatecas 98000, Mexico; \\ jose.celaya@uaz.edu.mx (J.M.C.-P.); analuisa.hernandezgutierrez@unizacatecas.edu.mx (A.L.H.-G.); \\ morenob20@uaz.edu.mx (A.M.-B.); ericgalvan@uaz.edu.mx (C.E.G.-T.); gatejo@uaz.edu.mx (J.I.G.-T.) \\ 3 INFOTEC-Center for Research and Innovation in Information and Communication, \\ Ciudad de México 14050, Mexico; edgar.gonzalezf@infotec.mx \\ 4 Postgraduate Program of Engineering and Applied Technology (National Laboratory CONACYT-SEDEAM), \\ Autonomous University of Zacatecas, Zacatecas 98000, Mexico; ricardolopezrobles@outlook.com \\ * Correspondence: hamurabigr@uaz.edu.mx
}

Received: 3 August 2020; Accepted: 2 September 2020; Published: 22 October 2020

\begin{abstract}
According to the United Nations, 70\% of the world's population will live in cities by 2050 . This growth will be reflected in the demand for better services that should be adjusted to the collective and individual needs of the population. Governments and organizations are working on defining and implementing strategies that will enable them to respond to these challenges. The main challenges are related to transport and its management, considering transportation as a core issue in the economy, sustainability, and development of the regions. In this way, the Intelligent Transportation Systems (ITS) play a key role in the response to these scenarios, being that they are the framework where the new hardware and software tools are integrated, allowing an efficient development of transportation systems management, attending to aspects such as: traffic management, communications between vehicles and infrastructures, and security, among others. Nevertheless, the concept of ITS evolves rapidly so it is necessary to understand its evolution. To do that, the current research develops a thematic analysis of ITS in literature, evaluating the intellectual structure and its evolution using SciMAT, quantifying the main bibliometric performance indicators, and identifying the main research areas, authors, journals, and countries. To this purpose, the publications related to ITS from 1993 to 2019 available in the Web of Science (WoS) Core Collection were retrieved (7649 publications) and analyzed. Finally, one of the main results is the latest research themes map of ITS, considering its intellectual structure, evolution, and relationship. It assists in the definition and implementation of strategies, the identification of the scientific, academic, and business opportunities, and future research lines to consolidate the role of ITS in the new city models.
\end{abstract}

Keywords: Intelligent Transportation Systems; sustainability; automotive industry; intelligent vehicles; smart mobility; strategic intelligence; competitive intelligence; bibliometric analysis; science mapping; SciMAT 


\section{Introduction}

The society is immersed in complex and rapidly changing scenarios. These scenarios demand dynamic strategies and innovative solutions, but above all, they should be sustainable over time. One of the main challenges facing society is related to population and city growth, and how this demands intelligent, lean, and sustainable transport solutions [1]. Furthermore, ITS are related to the new models that seek to develop more compact, intelligent, and sustainable cities, which relate urban planning and transport in the most immediate and future scenarios of these cities [2-4]. It is no longer enough to define strategies that only consider the increase of infrastructures, keeping in mind that economic resources are limited [5].

Nowadays, Intelligent Transportation Systems (ITS) are presented as a sustainable solution to the abovementioned challenge in urban and interurban areas. ITS are a commitment to more sustainable mobility, based on innovation and flexibility, where aspects such as the effectiveness and efficiency of transport and provision of security to users are the drivers [6-9]. The ITS purpose is to develop transport systems through solutions that improve the quality, quantity, flow, and access to information related to transport and traffic, both individually and collectively. In parallel, ITS consider infrastructures and vehicles from a holistic approach that integrates all stakeholders [10]. In addition, they are growing rapidly and the transport sector is a cross-cutting research field to other knowledge areas [11,12].

The heterogeneity, novelty, and evolution of the ITS field make difficult the comprehension and application of the core research areas, limiting the capacity of the agents to optimize resources and define strategies that allow to adequately deploy the latest advances in terms of ITS. For this reason, researchers and professionals are interested in evaluating the growth and evolution of the core themes and the relationship among them, in order to identify opportunities, trends, and applications.

Taking into account the above, it is essential to know the current state of the ITS field, identifying the main research themes, authors, organizations, and countries involved, as well as the main trends, in order to provide the necessary support to all stakeholders who are working in this knowledge field [13].

To do this, bibliometric tools and methods are two of the most accepted and common techniques for analyzing the results of basic and applied research. These types of methods are increasingly valued as mechanisms for evaluating academic, scientific, and business evolution, productivity, impact, and quality.

In this regard, there are bibliometric analyses of ITS in literature based on different approaches, such as intellectual structure [14-18], publications [19,20], authorship [21-24], and journals [25], or different areas within the transport field, such urban smart mobility [26], automotive technologies [27,28], and automotive supply chain [29]. However, the abovementioned researches are focused on a specific topic, which highlights the opportunity for a holistic approach that ensures consideration of all themes, their forms, and components included in the literature.

Therefore, the central objective of this research is to establish a holistic bibliometric analysis that evaluates the growth, evolution, and performance of the ITS research field and updates the intellectual structure of ITS from 1993 to 2019 [30,31]. It will assist any stakeholder to define, develop, and implement ITS strategies and to identify the main authors, organizations, journals, and research themes from a complete longitudinal science mapping analysis, where the intellectual structure is analyzed from a holistic approach.

Lastly, the rest of the publication is composed in the following way. Section 2 describes the methodology applied to the current research. Section 3 determines the performance bibliometric analysis, including the principal stakeholders (countries, organizations, and authors), sources, subjects, and publications. After this, Section 4 shows the science mapping analysis of intelligent transportation systems in two ways: strategic diagrams and a longitudinal evolution map. Finally, Section 5 recapitulates the key findings and concludes the research. 


\section{Methodology and Data set}

A detailed methodology was developed in order to analyze the growth, performance, and evolution of the ITS research field and its core research themes, considering the existing publications and their impacts. Additionally, it estimated performance through the analysis of the most relevant bibliometric indicators and defined a science map to uncover the evolution of the ITS research field (Figure 1a).

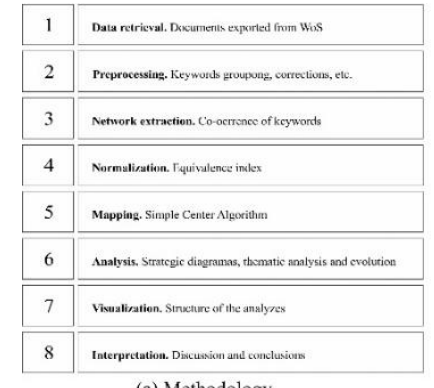

(a) Methodology

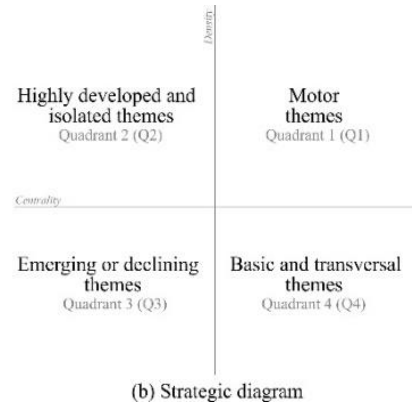

(b) Strategic diagram

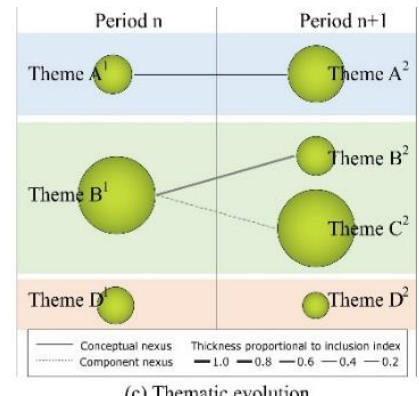

(c) Thematic evolution

Figure 1. This figure shows the (a) methodology, (b) structure of the strategic diagram and (c) thematic evolution map used to describe the progress of the themes related to Intelligent Transportation Systems (ITS).

The methodology employed was structured in two lines: bibliometric performance analysis and conceptual science mapping analysis. Initially, bibliometric performance analysis was grounded in bibliometric indicators that calculated the author's production and its impact achieved. In addition, the most relevant publications within the ITS research field were recognized using the h-index and $\mathrm{H}$-Classics approaches. Furthermore, a conceptual science mapping analysis grounded in the co-words network was developed using SciMAT [32-36]. This thematic analysis was based on a four-stage approach: (i) ITS research themes identification [37], (ii) visualization of the ITS research themes and the thematic network [38], (iii) definition of ITS thematic areas [39], and (iv) ITS research field performance analysis [40]. The ITS research themes recognized were visualized based on the density and centrality values, using two specified tools: thematic network and strategic diagram. The density quantified the internal strength of the network, and the centrality quantified the degree of interaction of a network with other networks [41-44].

To do that, the ITS research themes were organized in a strategic diagram (Figure 1b) and a thematic evolution map (Figure 1c). The strategic diagram is a two-dimensional map distributed in four quadrants according to significance, where the ITS research themes are exemplified as spheres, with the volume being proportional to the number of associated publications [45]. Quadrant 1-Motor themes (Q1): The themes within this area are important to structure and develop the ITS research field. Quadrant 2-Highly developed and isolated themes (Q2): The themes within this area are important but they do not have enough significance to be considered more than peripheral activities or very specialized themes for the ITS research field. Quadrant 3-Emerging or declining themes (Q3): The ITS research themes within this area are weak, but this weakness can be understood as disappearing or emerging themes. Quadrant 4-Basic and transversal themes (Q4): The themes within this area are not well-developed, but are significant for the ITS research field.

The thematic evolution map is a longitudinal framework, which allowed tracking and analyzing the growth and evolution of an ITS research field throughout successive time periods. Moreover, an ITS research field performance analysis of a thematic area using the key bibliometric indicators was developed.

Finally, SciMAT allows the definition and use of methodologies for the analysis of scientific maps according to the research needs and the period of time analyzed. In addition, SciMAT enriches the results using bibliometric indicators of quality, impact, and performance. SciMAT research is framed in a longitudinal context to explore the evolution of the various structural aspects of a science field [46]. 


\section{Data set}

Based on previous reviews of the state of the art, the current publication emphasizes the analysis of the ITS concept from a global approach, omitting regional conditions (e.g., United Kingdom approach) for further analysis. The data was retrieved from the Web of Science (WoS) Core Collection, bearing in mind that it is the one of the most important databases in the world, covering a wide range of knowledge areas and enabling comparisons across these. To do that, the following advance query was used: TS = ("intelligent transportation system" OR "intelligent transportation systems"), [refined by]: DOCUMENT TYPES: (REVIEW OR PROCEEDINGS PAPER OR ARTICLE) AND [excluding] PUBLICATION YEARS: (2020), Timespan: All years. Indexes: SCI-EXPANDED, SSCI, CPCI-S, AEHCI, CPCI-SSH, BKCI-S, BKCI-SSH, ESCI, IC, CCR-EXPANDED. In addition, to improve the quality of the knowledge base, it was limited to Reviews, Proceedings papers, and Articles published in English. The ITS query retrieved a total of 7649 publications from 1993 to 2019, of which 4427 (57.88\%) were Proceedings papers, 3422 (44.74\%) Articles, and 90 (1.18\%) Reviews. Finally, it is important to mention that one publication could be an article and a review, or article and proceeding paper, and, on the other hand, 1075 of these documents were available in open access.

For the evaluation and analysis of the growth and evolution of the ITS research field and to avoid a flatness of the data, a period of continuous and sufficient productivity was selected. The total years were divided into successive periods. In this way, the periods were commonly used to cover similar time spans; given the low number of publications in the early years, the best alternative in the current research was to split the time spans into similar periods. Consequently, the analysis period (1993-2019) was divided into five comparable sets: 1993-1999 (Period 1); 2000-2004 (Period 2); 2005-2009 (Period 3); 2010-2014 (Period 4), and 2015-2019 (Period 5). Finally, it is particularly important to emphasize that 2020 was not included in the science mapping analysis because it is still active. On the other hand, a de-duplicating process was also applied to improve data quality by grouping terms or concepts that represent the same meaning or notion (e.g., "ITS", "INTELLIGENT-TRANSPORTATION-SYSTEM" and "ITS-INTELLIGENT-TRANSPORTATION-SYSTEM" were merged as “INTELLIGENT-TRANSPORTATION-SYSTEM-(ITS)”).

Finally, the citations and bibliographic information of these documents were also used in this research; these were collected up to 31 July 2020.

\section{Performance Bibliometric Analysis of the Intelligent Transportation Systems}

The ITS research field performance was analyzed through the evaluation of the following bibliometric indicators: most productive authors, received citations, publications, most productive organizations, geographic distribution, and h-index, among others [47]. Consequently, the bibliometric performance analysis, initially based on the evaluation of the publications and their citations, was developed with the purpose of evaluating and validating the field's growth and evolution. Finally, the impact of the publications was evaluated by analyzing the research areas, journals, and authors.

\subsection{Performance and Impact Indicators}

The distribution of citations and publications per year related to the ITS research field is shown in Figure 2. In this figure it can be observed that both publications and citations were growing year by year since the first publication related to ITS. Nevertheless, in 1999 and 2010 indicators fell, but these were not considered relevant to the development of the ITS research field. Furthermore, 2019 was slightly higher than 2018, because the accepted publications in the last year were not indexed earlier than the collection date given previously. 


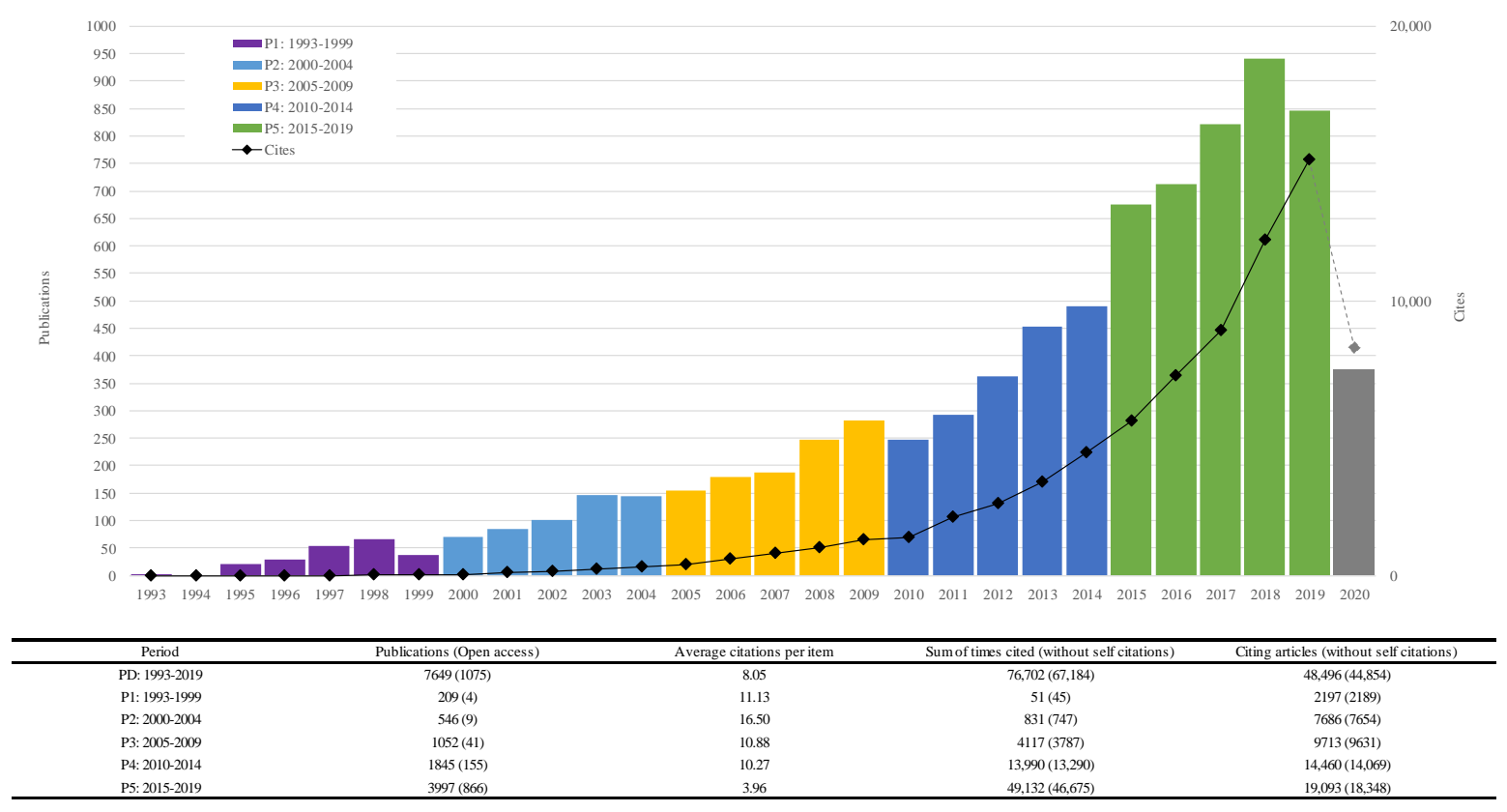

Figure 2. Distribution of citations and publications by year and period from 1993 to 2019. The bars represent the number of publications per year (left) published and the solid line corresponds to the citations (right).

In terms of production, at the beginning of this century sustained growth patterns of five years were observed, a reference that was used to determine the length of the evaluation periods. The growth registered in each of the periods exceeded $75 \%$, but in some cases it reached more than $100 \%$. The themes that supported part of this growth will be identified later in this paper.

In addition to this data, the first significant increase in citations occurred at the beginning of this decade, where the citations grew broadly and rapidly, compared to previous years. For the following years, the average rate of citation distribution grew regularly.

This development profile exposed the growing interest in the ITS research field within the academic, scientific, and business communities. Nevertheless, it is important to point out that these publications only mentioned those that explicitly included the concept of ITS, and that in the literature there may have been more concepts close to it that could be considered in its growth, such as big data, artificial intelligence, and smart cities, among others.

In the light of the pattern of development observed, it can be presumed that this progressive growth will continue. In accordance with J. Wang, the most relevant publications are normally those that were published earliest due to the time span between publication and reference [37]. It is expected that a publication needs between three and seven years to reach its highest number of citations.

\subsection{Most Productive and Most Cited Authors, Organizations, Geographic Distribution of Publications and Research Areas}

Expanding the notions explored in previous points, it was also important to note the most cited and productive authors, journals, countries, and research areas. Thus, it complemented the bibliometric performance analysis of the ITS and allowed an evaluation of where developments have occurred.

Thus, the most cited authors and most productive authors in the ITS research field from 1993 to 2019, according to WoS, are presented in Table 1. There was a tie in some rank positions between various authors; thus, all of them were included in alphabetical order. It indicates that only three of the most productive authors were among the most cited ones: Wang, F. Y. (32 publications and 2458 citations), Milanes, V. (31 publications and 1217 citations), and Chen, C. (29 publications and 890 citations). 
Table 1. The most productive authors and most cited authors from 1993 to 2019 in the ITS field according Web of Science (WoS).

\begin{tabular}{cccc}
\hline Publications & Author(s) (Citations) & Citations & Author(s) (Publications) \\
\hline 84 & Zhang, Y. (711) & 2458 & Wang, F. Y. (32) \\
36 & Boukerche, A. (229) & 1260 & Karlaftis, M. G. (4) \\
35 & Zhang, J. (188) & 1217 & Milanes, V. (31) \\
34 & Li, X. (367) & 1038 & Vlahogianni, E. I. (10) \\
33 & Onieva, E. (527); Zhang, L. (209) & 1012 & Lv, Y. S. (12) \\
32 & Wang, F. Y. (2458) & 1003 & Golias, J. C. (5) \\
31 & Milanes, V. (1217); Perez, J. (707); & 978 & Li, Z. X. (8) \\
30 & Wang, X. (304); Wang, Y. (51) & & Chen, C. (29) \\
29 & Wang, J. (133) & 890 & Duan, Y. J. (4) \\
28 & Chen, C. (890) & 887 & Kang, W. W. (4) \\
\hline
\end{tabular}

In this way, the most productive organizations were the Chinese Academy of Sciences (203 publications), University of California System (157 publications), Tsinghua University (156 publications), Beijing Jiaotong University (127 publications), State University System of Florida (97 publications), Tongji University (86 publications), Shanghai Jiao Tong University (80 publications), Southeast University China (78 publications), Institute of Automation CAS (76 publications), National Chiao Tung University (76 publications), Indian Institute of Technology System (68 publications), and University of California at Berkeley (68 publications).

Furthermore, it should be highlighted that the most productive authors were related to research centers referred to in the transport sector, such as the Research Center of Intelligent Transportation Systems (China), Paradise Research Laboratory (Canada), Institute of Automation (China), Toronto Intelligent Transportation Systems Centre (Canada), Tecnalia Research \& Innovation (Spain), Shanghai Key Laboratory of Trustworthy Computing (China), among others.

Regarding the most productive countries from 1993 to 2019, China (2222 publications) and United States (1680 publications) were the leaders, followed by India (430 publications), Canada (364 publications), Spain (338 publications), Taiwan (338 publications), South Korea (307 publications), France (288 publications), Italy (259 publications), Germany (243 publications), and Japan (234 publications). All of these countries were leaders in the transport sector, thus, their commitment to research and development in the ITS field.

Along this line, two different agents were identified. On the one side were the leading countries in the transport sector that had the main manufacturers of vehicles and technologies related to transport. On the other side were countries with the capacity and need to develop more modern, efficient, and intelligent transport systems. In both cases, the developments in ITS were driven strongly by the main countries in the transport industry, socioeconomic needs, and environmental demands.

Furthermore, although the countries mentioned above had broad strategies to develop in the ITS field, it was possible to detect some upper strategies at a regional level. America was focused on mobility and emergency systems, new notifications systems, and the processing of data in real time. Europe was oriented to improve the infrastructures, road and vehicle safety, and protection of the environment. Finally, Asia was involved in the new advanced information and telecommunications technologies to traffic control and navigation. Obviously, the countries mentioned above had a comprehensive strategy for the development of the ITS field.

The journals with highest number of publications related to the ITS research field were: IEEE Transactions on Intelligent Transportation Systems (398 publications), Transportation Research Record (236 publications), IEEE International Conference on Intelligent Transportation Systems (178 publications), IEEE Access (142 publications), IET Intelligent Transport Systems (139 publications), Lecture Notes In Computer Science (133 publications), Transportation Research. Part C: Emerging Technologies (113 publications), IEEE Transactions on Vehicular Technology (101 publications), IEEE Vehicular 
Technology Conference Proceedings (101 publications), Sensors (100 publications), and Journal of Intelligent Transportation Systems (74 publications). In this regard, it should be noted that the journals were included in different research areas that concentrate the core publications, including issues from transport and mobility to new technologies.

On the other hand, the most relevant research areas related to the ITS research field were Engineering (4347 publications), Computer science (3432 publications), Transportation (2563 publications), Telecommunications (1773 publications), Automation control systems (624 publications), Operations research management science (204 publications), Robotics (195 publications), Instruments instrumentation (185 publications), Imaging science photographic technology (182 publications), and Optics (138 publications).

\subsection{Citations Classics}

In what follows an outline is provided of the h-index and H-Classics analysis. The H-Classics method [34] is based on the well-known h-index [35]. This mechanism works as an impartial measure to organize the identification of classic publications in the ITS research field. One of the main problems when detecting the classic or highly cited papers is the establishment of the thresholds. That is, some approaches select the $\mathrm{N}$ most cited papers, and others select the papers with more than $\mathrm{C}$ citations. Both methods are biased, since the setting of the threshold is very arbitrary. Contrary to this, the H-Classics approach uses the well-known h-index as thresholds. In that way, we could compute the h-index of a set of articles, and therefore, this number would be the cut-off point.

In summary, this mechanism used the H-Classics method to determine a classic publication in the ITS research field, and therefore, identified the journals, authors, and countries with higher contributions [44]. The H-Classics and h-index minimize the disproportionate weighting of the publications cited regularly or publications that have not yet been cited, empowering the analysis of publications within an ITS research field.

Firstly, the advance query executed in the Web of Science (WoS) Core Collection had an h-index value of 106, meaning that relevant publications had more than 106 citations (Appendix A, Table A1). Therefore, the total number of citations and the most relevant publications distributions in the period evaluated (1993-2019) are presented in Figure 3.

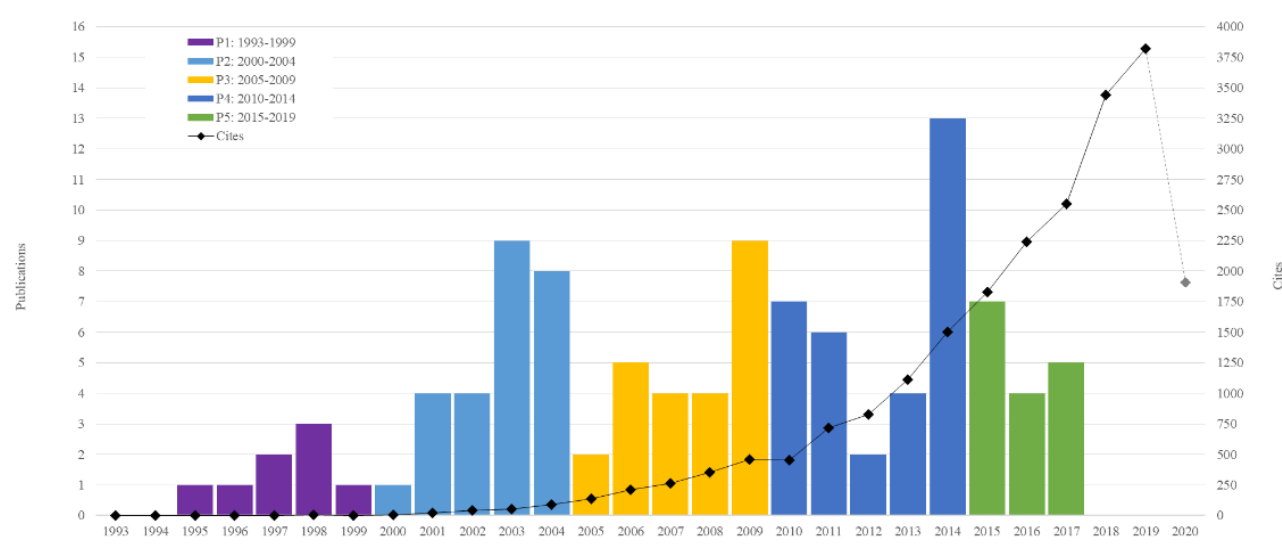

Figure 3. Distribution of H-Classics publications and citations by year and period from 1993 to 2019. The solid line corresponds to the number of citations (right) and the bars represents the number of publications per year (left) published.

Based on the outcomes of the advance query executed, the citation performance for the H-Classics publications was reported in the following indicators: Sum of times cited (without self-citations): 22,211 (22,079), Citing articles (without self-citations): 16,751 (16,704), and Average citations per 
publication: 209.54. Table A1 shows the citation classics papers identified by means of the H-Classics concept.

It is important to emphasize that all the periods analyzed had publications considered relevant to the development of the ITS field. The largest number of reference publications was concentrated in the fourth period ( 32 publications), followed by the second period ( 26 publications), third period (24 publications), fifth period (16 publications) and first period (8 publications), respectively. In addition, Figure 3 indicates that there were publications that remained as references after the seven-year period had elapsed, which suggests that these documents are part of the core of the ITS research field [48]. The authors with highest number of publications and its citations and the most cited authors and their publications are included in Table 2.

Table 2. The most productive authors and most cited authors from 1993 to 2019 in the ITS field according H-Classics.

\begin{tabular}{|c|c|c|c|}
\hline Publications & Author(s) (Cites) & Cites & Author(s) (Publications) \\
\hline 5 & Wang, F. Y. (1913) & 1913 & Wang, F. Y. (5) \\
\hline 4 & Karlaftis, M. G. (1260) & 1260 & Karlaftis, M. G. (4) \\
\hline 3 & $\begin{array}{c}\text { Adeli, H. (480); Golias, J. C. (985); } \\
\text { Milanes, V. (648); Rilett, L. R. (422); } \\
\text { Shladover, S. E. (616); Vlahogianni, E. I. (985); } \\
\text { Williams, B. M. (764) }\end{array}$ & 985 & $\begin{array}{c}\text { Golias, J. C. (3); } \\
\text { Vlahogianni, E. I. (3) }\end{array}$ \\
\hline 2 & $\begin{array}{l}\text { Bertozzi, M. (371); Broggi, A. (371); } \\
\text { Chabini, I. (222); Cheng, X. (413); Dia, H. (379); } \\
\text { Fan, K. C. (253); Fascioli, A. (371); } \\
\text { Jiang, X. M. (359); Li, L. (223); } \\
\text { Trepanier, M. (522); Yan, G. J. (376); } \\
\text { Yang, L. Q. (320); Zeadally, S. (227) }\end{array}$ & 826 & $\begin{array}{c}\text { Duan, Y. J. (1); } \\
\text { Kang, W. W. (1); } \\
\text { Li, Z. X. (1); Lv, Y. S. (1) }\end{array}$ \\
\hline 1 & 288 authors & $>764-106$ & 302 authors \\
\hline
\end{tabular}

In this way, the most relevant organizations included in the H-Classics were Chinese Academy of Sciences (8 publications), University of California System (7 publications), Massachusetts Institute of Technology (5 publications), National Technical University of Athens (5 publications), University of California at Berkeley (5 publications), Institute of Automation CAS (4 publications), Tsinghua University (4 publications), University of Waterloo (4 publications), National University of Defense Technology China (3 publications), Ohio State University (3 publications), Shanghai Jiao Tong University (3 publications), State University System of Florida (3 publications), University of Montreal (3 publications), University of Washington (3 publications), and University of Washington, Seattle (3 publications).

The countries with the highest numbers of most cited articles were United States (50 publications), China (22 publications), Canada (9 publications), Greece (8 publications), Italy (8 publications), France (6 publications), United Kingdom (6 publications), Taiwan (5 publications), Australia (4 publications), Netherlands (3 publications), and Singapore (3 publications). These data strongly agreed with the results described previously.

On the other hand, the sources with the highest number of publications identified according to h-index were IEEE Transactions on Intelligent Transportation Systems (26 publications), Transportation Research. Part C: Emerging Technologies (11 publications), Journal of Transportation Engineering (7 publications), IEEE Communications Magazine (6 publications), IEEE Transactions on Vehicular Technology (4 publications), IEEE Internet of Things Journal (3 publications), IEEE Communications Surveys and Tutorials (2 publications), IEEE Wireless Communications (2 publications), Journal of Intelligent Transportation Systems (2 publications), Journal of Network and Computer Applications (2 publications), Journal of Transportation Engineering ASCE (2 publications), and Transportation Research Record (2 publications). Furthermore, the research areas for h-index publications were Engineering (71 publications), Transportation (67 publications), Computer science (26 publications), Telecommunications (25 publications), Business economics (5 publications), Operations research 
management science (5 publications), Automation control systems (3 publications), and Environmental sciences ecology (2 publications), mainly.

Finally, the field of ITS - understood as advanced applications and technologies which, without embodying intelligence as such, aim to provide innovative products and services relating to traffic management and different modes of transport, and to enable users to be informed and make safer, more coordinated, and "smarter" use of transport networks-is still evolving in terms of quality and quantity and consolidating its role as a reference point for improving environmental and transport systems.

\section{Science Mapping Analysis of Intelligent Transportation Systems}

Applying the methodology described above, the next step provides an overview of science mapping and relations between the core themes in the ITS research field. The content of the publications will first be analyzed, followed by the science map using SciMAT. To do that, the bibliographic information of the publications retrieved was used as a source of the research.

\subsection{Analysis of the Themes and Content of the Publications}

Considering the knowledge base and the defined periods as starting points, the strategic diagrams for each of them are presented below. Specifically, the strategic diagram is a four-quadrant diagram that identifies: (Q1) Motor themes, (Q2) Highly developed and isolated themes, (Q3) Emerging or declining themes, and (Q4) Basic and transversal themes [43]. Themes are represented by spheres that are sized in proportion to the number of publications that they include. The citations are indicated between parentheses, and the themes are arranged according to their relation to other themes. Finally, it allows to visualize the most relevant themes of the publications included during a period of time [41,49].

During 1993-1999 period, ten themes related to the ITS research field were identified (see Figure 4). The themes that were considered core to structure the ITS research field were: TRAFFIC-ROUTE-AND-GUIDANCE, TRAFFIC-SAFETY, AUTOMATED-HIGHWAY-SYSTEM-(AHS), ADVANCED-TRAVELER-INFORMATION-SYSTEM-(ATIS) and TRAFFIC-MANAGEMENT. Based on the above, a brief summary of the status of each quadrant is offered.

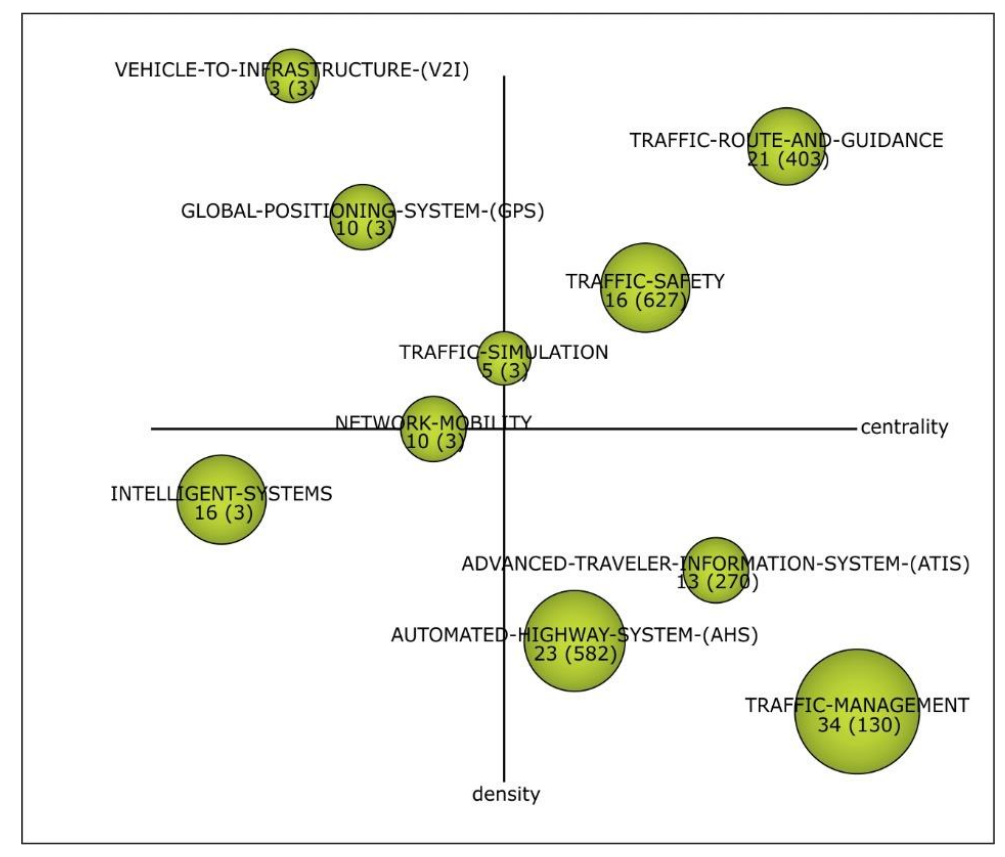

Figure 4. Strategic diagram from 1993 to 1999. 
TRAFFIC-ROUTE-AND-GUIDANCE and TRAFFIC-SAFFETY appear as a Motor themes. These themes are mainly related with traveler information systems, dynamic networks, vehicle control, traffic density, and autonomous vehicle systems.

GLOBAL-POSITIONING-SYSTEMS-(GPS) appears as a Highly developed and isolated theme. It is mainly focused on the vehicle detection, map matching, location referencing, and web technology.

INTELLIGENT-SYSTEMS, which is mainly focused on data communication and multi-agent systems, appears as unique Emerging or declining themes.

AUTOMATED-HIGHWAY-SYSTEMS-(AHS) and TRAFFIC-MANAGEMENT appear as the main Basic and transversal themes.

From 2000 to 2004, 20 themes related to the ITS research field were identified, of which 13 were new themes and seven were recurrent themes from the previous period. The structure of this period was mainly Motor themes, but it had themes in all four quadrants (see Figure 5).

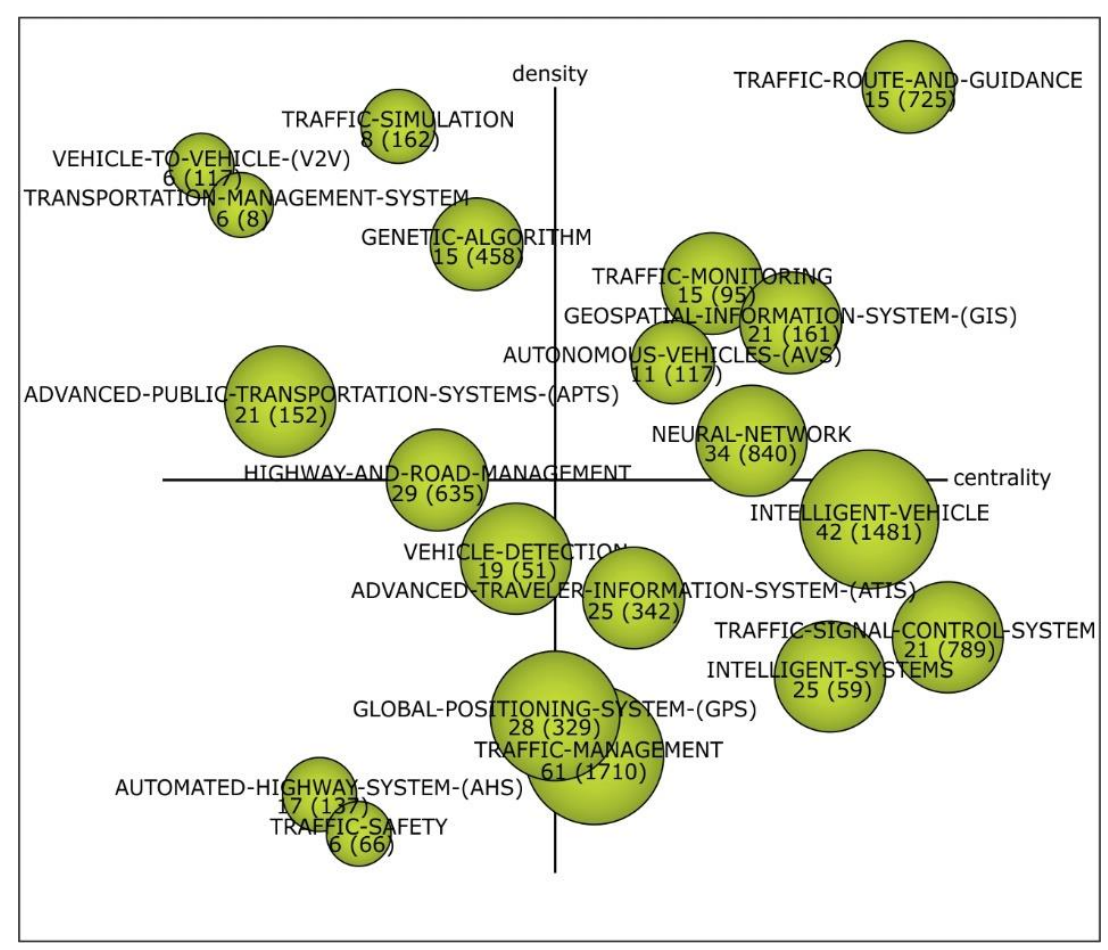

Figure 5. Strategic diagram from 2000 to 2004.

Consistent with the analysis, eight themes were considered core in the research field: AUTONOMOUS-VEHICLES-(AVS), TRAFFIC-ROUTE-AND-GUIDANCE, TRAFFIC-MONITORING, TRAFFIC-MANAGEMENT, INTELLIGENT-VEHICLE, TRAFFIC-SIGNAL-CONTROL-SYSTEM, MULTI-AGENT-SYSTEMS, and GEOSPATIAL-INFORMATION-SYSTEM-(GIS). Based on the above, a brief summary of each quadrant is offered:

TRAFFIC-MONITORING, which is mainly focused on image sequence analysis and machine vision metrology, appears as new Motor themes.

The Highly developed and isolated themes are TRAFFIC-SIMULATION, GENETIC-ALGORITHM, HIGHWAY-AND-ROAD-MANAGEMENT, and NEURAL-NETWORK.

VEHICLE-DETECTION and GLOBAL-POSITIONING-SYSTEM-(GPS), mainly related with the vehicle navigation, appear as a most relevant themes within Emerging or declining themes. 
The main Basic and transversal themes are INTELLIGENT VEHICLE and TRAFFIC-MANAGEMENT, and are focused on traffic and intelligent technologies.

During the period 2005-2009, 14 themes were identified, of which five were new themes, as shown in Figure 6.

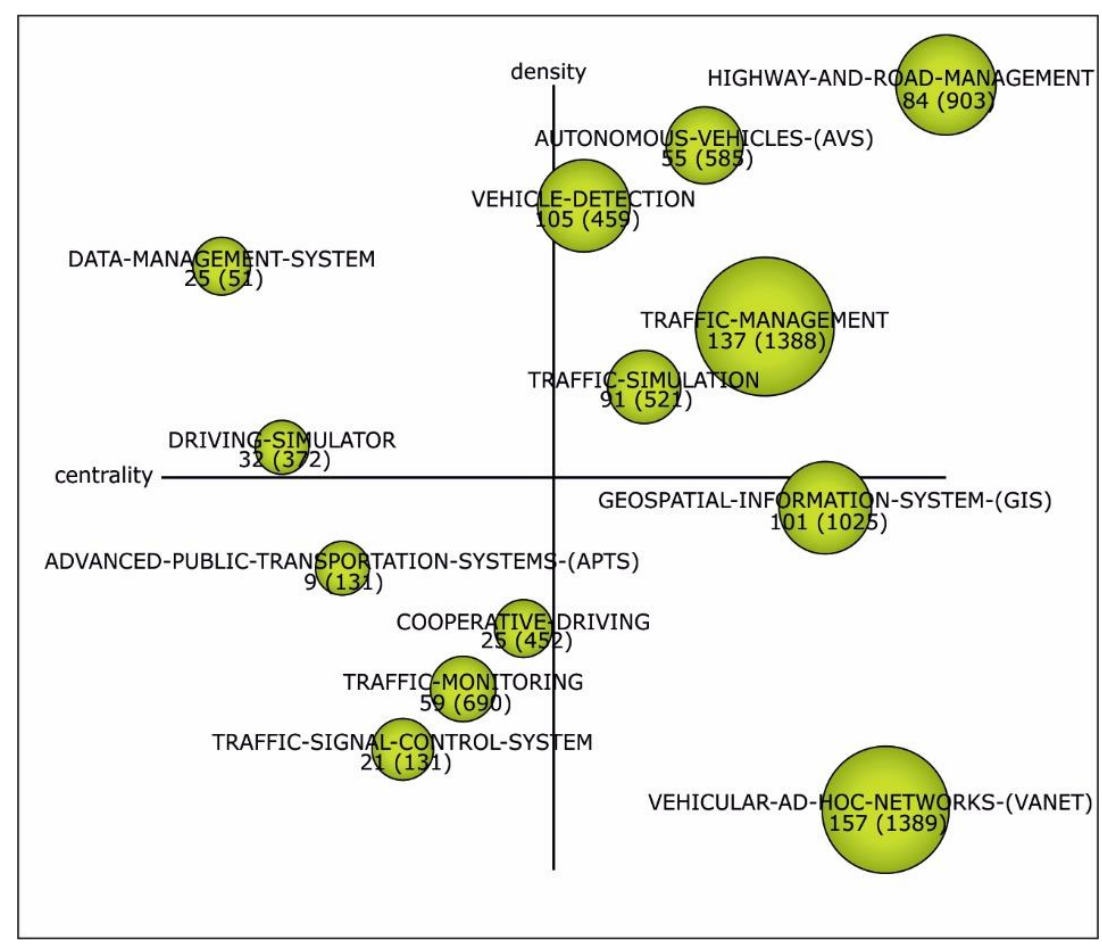

Figure 6. Strategic diagrams from 2005 to 2009.

In this respect, nine themes were reflected as relevant to the evolution, growth, and development of the ITS research field: VEHICLE-DETECTION, HIGHWAY-AND-ROAD-MANAGEMENT, TRAFFIC-MANAGEMENT, TRAFFIC-SIMULATION, AUTONOMOUS-VEHICLES-(AVS), VEHICULAR-AD-HOC-NETWORKS-(VANET), and GEOSPATIAL-INFORMATION-SYSTEM-(GIS). Based on the above, a brief summary of the status of each quadrant is offered:

TRAFFIC-MANAGEMENT appears as a Motor theme with high density and centrality values. This theme has gone from Basic and transversal themes to Motor themes. It is mainly focused on the real-time recognition, neural network, intermodal transportation networks, and integrated transportation system.

The Highly developed and isolated themes integrates two new themes, DATA-MANAGEMENT-SYSTEM and DRIVING-SIMULATOR.

TRAFFIC-MONITORING and TRAFFIC-SIGNAL-CONTROL-SYSTEM, which are mainly focused on traffic condition, wireless technologies and image recognition, are the most relevant Emerging or declining themes.

VEHICULAR-AD-HOC-NETWORKS-(VANET), which is mainly focused on intelligent vehicle, connectivity, wireless communication and vehicle to vehicle $(\mathrm{V} 2 \mathrm{~V})$, appears as new Basic and transversal themes.

From 2010 to 2014, 15 themes related to ITS research field were identified, five were new themes and 11 were recurrent themes from the previous period. The structure of this period was distributed among all the quadrants, as shown in Figure 7. 


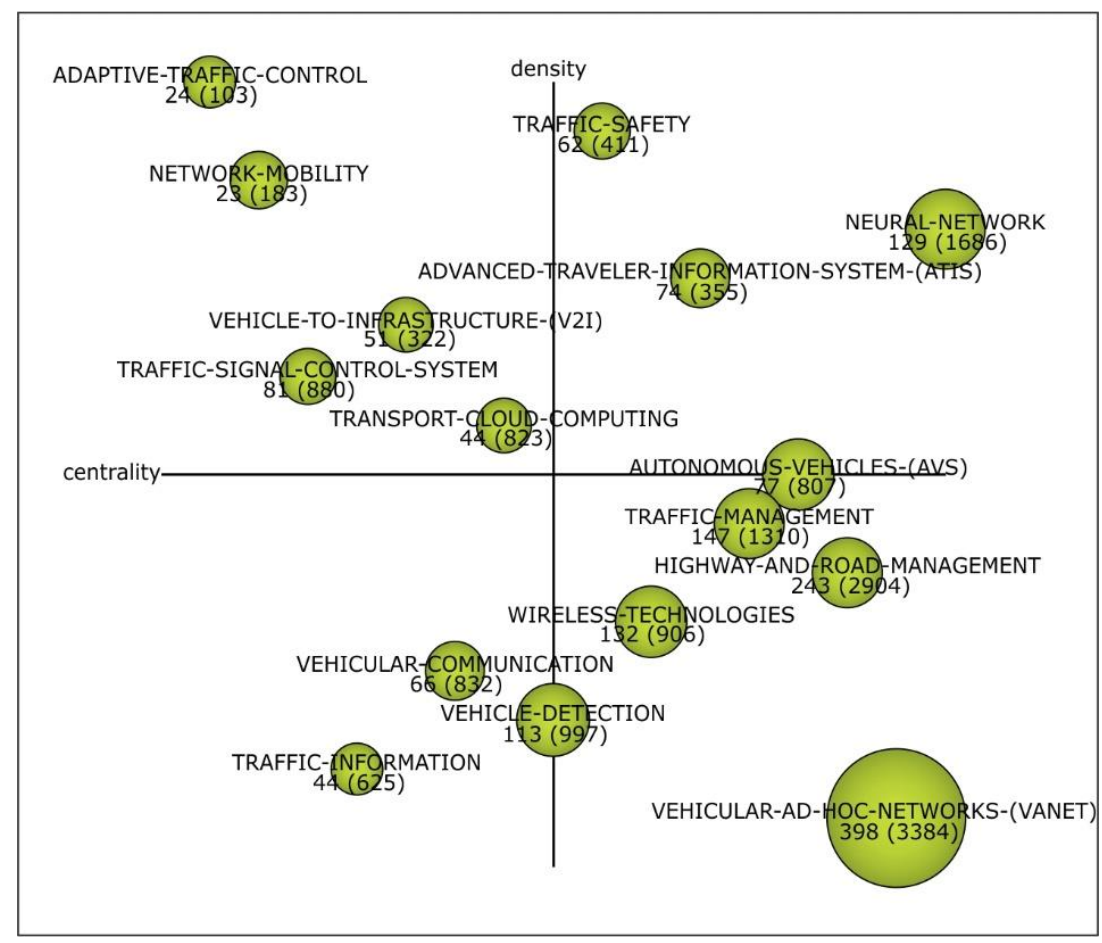

Figure 7. Strategic diagrams from 2010 to 2014.

Consistent with the analysis, eight themes were considered core in the ITS research field: TRAFFIC-SAFETY, WIRELESS-TECHNOLOGIES, ADVANCED-TRAVELER-INFORMATION-SYSTEM-(ATIS), I NEURAL-NETWORK, TRAFFIC-MANAGEMENT, AUTONOMOUS-VEHICLES-(AVS), VEHICULAR-AD-HOCNETWORKS-(VANET), and HIGHWAY-AND-ROAD-MANAGEMENT. Based on the above, a brief summary of each quadrant is offered:

AUTONOMOUS-VEHICLES-(AVS) and NEURAL-NETWORK appear as the most relevant Motor themes. These themes are mainly related with traffic prediction, machine learning, accident detection, and autonomous driving.

NETWORK-MOBILITY appears as a new and most relevant theme within Highly developed and isolated themes. It is primarily related with route optimization, mobility management, and new protocols.

The Emerging or declining themes integrate TRAFFIC-INFORMATION and VEHICULAR-COMMUNICATION as two new themes. VEHICLE-DETECTION is the main theme included in this quadrant and is related with loop detectors, vehicle tracking, sensor networks, and support vector machine.

WIRELESS-TECHNOLOGIES appears as new theme in the ITS research field and VEHICULAR-AD-HOC-NETWORKS-(VANET) appears as the most relevant Basic and transversal theme.

During the period 2015-2019, 18 themes were identified, six were new themes and 12 were recurrent themes from the preceding period, as shown in Figure 8. 


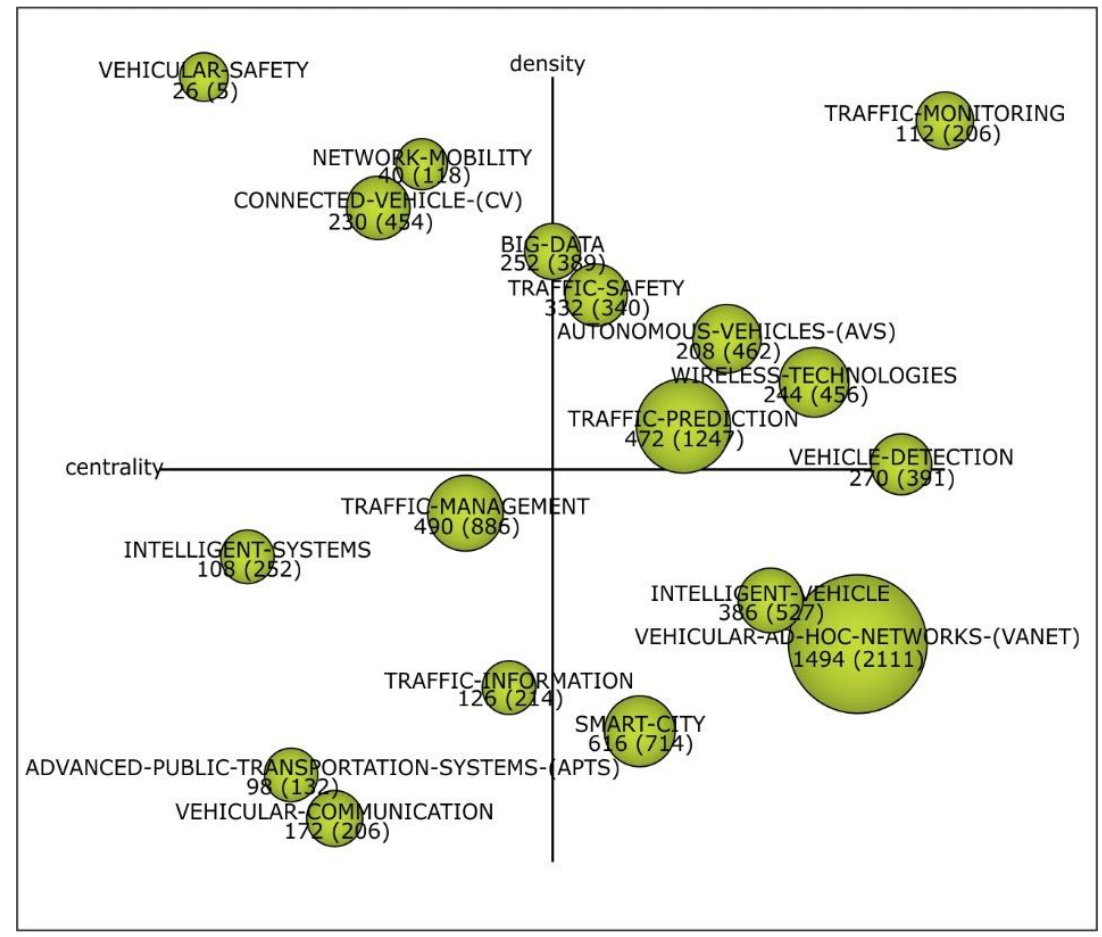

Figure 8. Strategic diagrams from 2015 to 2019.

Consistent with the analysis, ten themes were considered core in the research field: VEHICLE-DETECTION, TRAFFIC-SAFETY, AUTONOMOUS-VEHICLES-(AVS), WIRELESS-TECHNOLOGIES, TRAFFIC-PREDICTION, BIG-DATA, TRAFFIC-MONITORING, SMART-CITY, INTELLIGENT-VEHICLE, and VEHICULAR-AD-HOC-NETWORKS-(VANET). A brief summary of each quadrant is offered:

TRAFFIC-PREDICTION, which is primarily focused on neural network, traffic models and flow prediction, appears as a new and most important Motor theme.

The Highly developed and isolated themes are CONNECTED-VEHICLE-(CV), VEHICULAR-SAFETY, and NETWORK-MOBILITY, and are focused on themes related with safety and mobility.

TRAFFIC-MANAGEMENT and VEHICULAR-COMMUNICATION, mainly related with the vehicular and infrastructure communications, appear as most relevant themes within Emerging or declining themes.

The Basic and transversal themes are VEHICULAR-AD-HOC-NETWORKS-(VANET), SMART-CITY and INTELLIGENT-VEHICLE.

In this background, during the period 1993 to 2019, the most productive period in terms of themes was P2:2000-2004, with a total of 20 themes. This period was followed by P5:2015-2019, P4:2010-2014, P3:2005-2009, and P1:1993-1999, with 18, 15, 13, and 9 themes, respectively. Figure 9 shows the bibliometric indicators (publications, citations, and h-index average) for each strategic period.

The first period (1993-1999) included themes related to traffic guidance and infrastructures mainly, and covered sub-themes such as traveler information systems, electronic toll and traffic management, traffic density, vehicle control, dynamic route guidance, transport telematics, traffic center, data communication, transportation management system, traffic network, advance public transportation system, and the first developments of the intelligent and autonomous vehicle. In this way, these research themes and sub-themes established the starting point for the second period. 


\begin{tabular}{|c|c|c|c|c|c|}
\hline THEME & $\begin{array}{l}\mathrm{P} 1: \text { : 1993-1999 } \\
\end{array}$ & P2:2000-2004 & $P 3: 2005-2009$ & P4: 2010-2014 & P5: 2015-2019 \\
\hline $\begin{array}{l}\text { TRAFFIC-MANAGEMENT } \\
\end{array}$ & $\mathrm{Q} 4(34|130| 3)$ & $\mathrm{Q} 4(61|1710| 13)$ & Q1 (137|1388|16) & $\mathrm{Q}^{4}(147|1310| 17)$ & Q3 (490|886|12) \\
\hline INTELLIGENT-VEHICLE & & Q4 (42|1481|9) & & & Q4 (386|527|9) \\
\hline GLOBAL-POSITIONING-SYST EM-(GPS) & $\mathrm{Q}^{2}(10|3| 1)$ & Q4 (38| $329 \mid 5)$ & & & \\
\hline INTELLIGENT-SYSTEMS & $\mathrm{Q} 3(16|3| 1)$ & Q4 (25|59|1) & & & $\mathrm{Q} 3(108|252| 6)$ \\
\hline ADVANCED-TRAVELER-INFORMATION-SYSTEM-(ATIS) & $\mathrm{Q} 4(13|270| 1)$ & Q4 (25|342|4) & & Q1 (74|355|8) & \\
\hline TRAFFIC-SIGNAL-CONTROL-SYSTEM & & Q4 (21|789|6) & Q3 $(21|131| 4)$ & Q2 (81|880|13) & \\
\hline TRAFFIC-SAFETY & Q1 (21 $|403| 3)$ & Q3 (6|66|2) & & Q1 (62|411|10) & Q1 (332|340|6) \\
\hline VEHICLE-DETECTION & & $\mathrm{Q} 3(19|51| 3)$ & Q1 (105|459|8) & $\mathrm{Q} 4(113|997| 11)$ & Q1 (270|391|7) \\
\hline AUTOMATED-HIGHWAY-SYSTEM-(AHS) & Q4 (23|582|5) & $\mathrm{Q} 3(17|137| 2)$ & & & \\
\hline TRAFFIC-SIMULATION & Q2 (5|3|1) & $\mathrm{Q} 2(8|162| 2)$ & Q1 (91|521|11) & & - \\
\hline TRANSP ORTATION-MANAGEMENT-SYSTEM & & Q2 (6|8|1) & & & \\
\hline VEHICLE-TO-VEHICLE-(V2V) & & Q2 (6 $|117| 1)$ & & & - \\
\hline HIGHWAY-AND-ROAD-MANAGEMENT & & Q2 (29|635|8) & Q1 (84|903|12) & Q4 (243| 2904 | 25) & \\
\hline ADVANCED-PUBLIC-TRANSPORTATION-SYSTEMS(APTS) & & $\mathrm{Q} 2(21|152| 3)$ & Q3 (9|131|3) & & Q3 $(98|132| 3)$ \\
\hline GENETIC-ALGORIT HM & & $\mathrm{Q} 2(15|458| 4)$ & & & \\
\hline NEURAL-NETWORK & & Q1 (34|840|5) & & Q1 (129|1686|19) & \\
\hline GEOSPATIAL-INFORMATION-SYSTEM-(GIS) & & Q1 (21|161|4) & $\mathrm{Q} 4(101|1025| 13)$ & & \\
\hline TRAFFIC-MONIT ORING & & Q1 (15|95|3) & Q3 (59|690|7) & & Q1 (112|206|6) \\
\hline TRAFFIC-ROUTE-AND-GUIDANCE & Q1 (16|627|2) & Q1 (15|725|3) & & & \\
\hline AUTONOMOUS-VEHICLES(AVS) & & Q1 (11|117|1) & Q1 (55|585|8) & Q4 (77|807|11) & Q1 (208|462|7) \\
\hline VEHICLE-TO-INFRAST RUCT URE-(V2I) & $\mathrm{Q} 2(3|3| 1)$ & & & $\mathrm{Q} 2(51|322| 8)$ & \\
\hline NETWORK-MOBILITY & $\mathrm{Q} 2(10|3| 1)$ & & & Q2 (23|183|7) & $\mathrm{Q} 2(40|118| 4)$ \\
\hline VEHICULAR-AD-HOC-NET WORKS-(VANET) & . & & $\mathrm{Q} 4(167|1389| 15)$ & Q4 (398| $3384 \mid 28)$ & Q4 (1494|2111| 14) \\
\hline TRAFFIC-INFORMATION & - & & & Q3 (44|625|11) & $\mathrm{Q} 3(126|214| 6)$ \\
\hline VEHICULAR-COMMUNICATION & - & & - & Q3 (66|832|13) & Q3 (172|206|5) \\
\hline WIRELESS-TECHNOLOGIES & $\cdot$ & & & Q4 (132|906| 12) & Q1 (244| $456 \mid 8)$ \\
\hline COOPERATIVE-DRIVING & & & $\mathrm{Q} 3(25|452| 6)$ & & \\
\hline DATA-MANAGEMENT-SYST EM & & & $\mathrm{Q} 2(25|51| 2)$ & & \\
\hline DRIVING-SIMULATOR & - & & $\mathrm{Q} 2(32|372| 7)$ & & \\
\hline ADAPTIVE-TRAFFIC-CONTROL & - & & $\cdot$ & Q2 (24|103|5) & \\
\hline TRANSP ORT-CLOUD-COMPUTING & - & & - & Q2 (44 |823|6) & cesizenta \\
\hline & - & & - & - & Q1 (256|389|7) \\
\hline CONNECTED-VEHICLE-(CV) & & & & & Q2 (230|454|9) \\
\hline SMART-CITY & & & & & Q4 (616|714|10) \\
\hline $\begin{array}{l}\text { TRAFFIC-PREDICTION } \\
\text { VEIITIY }\end{array}$ & & & & & Q1 (472|1247|11) \\
\hline VEHICULAR-SAFETY & & & & & Q2 $(26|5| 1)$ \\
\hline
\end{tabular}

Figure 9. The bibliometric indicators (publications, citations, and h-index average) for each strategic period.

The second period (2000-2004) was focused on traffic guidance, control and management, infrastructures, and intelligent vehicle. During this period the themes of intelligent vehicle, autonomous vehicles, and vehicle-to-vehicle communications appeared as relevant. This situation opened up a new relationship between vehicles, infrastructure, and transport management systems. In this regard, the main sub-themes developed during this period were traffic network, dynamic routing and scheduling, traffic sign recognition, intelligent traveler information systems, predictive traffic information, vehicle tracking, traffic signal networks, intelligent traffic management systems, automatic vehicle guidance, road vehicle communication, and transportation sustainability.

The transport sector was affected during the third period by different global conditions. This situation was seen in the reduction of research topics between 2005 and 2009. The main themes covered were traffic management, vehicular ad hoc networks, and cooperative driving. This period was considered as a transition period due to the recession in the transport sector and the technological changes resulting from this. In this way, the sub-themes developed during this period were automated highway system, traffic route and guidance, integrated transportation systems, driver assistance systems, intelligent vehicle, vehicle and infrastructure communications, traffic prediction, and transportation management systems.

Having overcome the recession of the previous period, during the fourth period (2010-2014) research themes that focused mainly on intelligence applied to systems, infrastructures, and vehicles increased. Thus, the main sub-themes covered were traffic prediction, urban sustainable development, vehicle and infrastructure communications, intelligent vehicle, vehicle tracking, real-time traffic data, mobility management, advanced driver assistance systems, anticipatory driving, autonomous driving, and transportation management system.

The fifth period (2015-2019) was considered a living period, because it was an intense period in growth and strongly aligned with the previous period. It included themes related to traffic prediction, vehicular ad hoc networks, and autonomous vehicle. The main themes stood out for being oriented towards sustainable and intelligent mobility from the systems, infrastructures, and vehicles points of view. Moreover, the sub-themes developed were vehicle detection and tracking, flow prediction, energy management, real-time processing, computational intelligence, vehicle and infrastructure communications, driver assistance systems, machine learning and data mining, traffic information systems, and cooperative driving.

Based on the main themes observed in the periods analyzed, the function of ITS seemed a promising solution to improve transportation efficiency, traffic congestion, and safety; reduce emissions; 
promote the development of related industries; and increase energy efficiency. Finally, the strategic position of each ITS research theme recognized during these periods allowed the definition of three main thematic areas described below.

\subsection{Intelligent Transportation System Research Evolution Map}

In light of these, the ITS evolution map is shown in Figure 10. It is organized in three thematic areas: Traffic Management (red area); Communications, Infrastructures and Systems (blue area); and Intelligent and Autonomous Vehicle (green area); and it exposes the pattern of growth, development, and evolution within the knowledge area throughout the periods considered and the relationship between each ITS research theme [43].

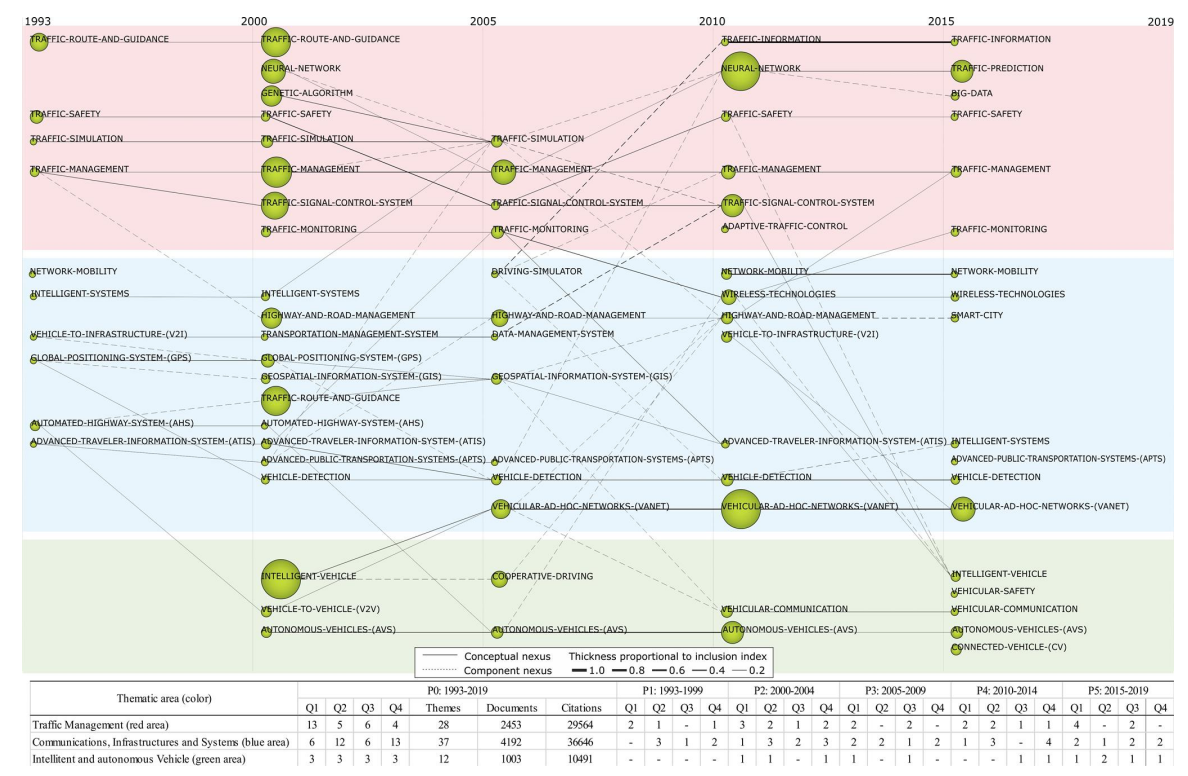

Figure 10. Thematic evolution of the ITS research field from 1993 to 2019. In the evolution map, three main thematic areas are recognized: Traffic Management (red area); Communications, Infrastructures and Systems (blue area); and Intelligent and Autonomous Vehicle (green area).

The main observations about the thematic evolution and performance of the thematic areas are presented below.

Communications, Infrastructures and Systems is the most representative thematic area within the conceptual evolution map of the ITS research field from 1993 to 2019. It accounts for 4192 documents and 36,646 citations. In terms of thematic composition and structure, it is composed of all the themes, but mainly by Basic and transversal themes, and Highly developed and isolated themes. These themes cover research lines such as HIGHWAY-AND-ROAD-MANAGEMENT, SMART-CITY, VIRTUAL-MOBILITY, GEOSPATIAL-INFORMATION-SYSTEM-(GIS), NETWORK-MOBILITY, VEHICLE-TO-INFRASTRUCTURE-(V2I), MULTI-AGENT-SYSTEMS, INTELLIGENT-SYSTEMS, GLOBAL-POSITIONING-SYSTEM-(GPS), TRANSPORTATION-MANAGEMENT-SYSTEM, or VEHICULAR-AD-HOC-NETWORKS-(VANET).

The second thematic area within the thematic evolution map is Traffic Management. It covers 2453 documents and 29,564 citations. It mainly integrates Highly developed and isolated themes, and Motor themes, although it also has a presence in the rest of the quadrants. These themes cover research themes such as TRAFFIC-SIMULATION, TRAFFIC-SAFETY, TRAFFIC-ROUTE-AND-GUIDANCE, TRAFFIC-MANAGEMENT, TRAFFIC-INFORMATION, NEURAL-NETWORK, TRAFFIC-SIGNAL-CONTROL-SYSTEM, or BIG-DATA.

Intelligent and Autonomous Vehicle is the third thematic area within the map. It has 1003 documents and 10,491 citations. This thematic area occupies all 
four quadrants in all periods evaluated. These include research themes such as AUTONOMOUS-VEHICLES-(AVS), CONNECTED-VEHICLE-(CV), INTELLIGENT-VEHICLE, VEHICLE-TO-VEHICLE-(V2V), or VEHICULAR-SAFETY.

The ITS research field is growing and strongly linked to other knowledge areas that are also growing, such as big data, smart cities, and IT technologies, among others. In addition, the ITS research field has a solid structure and strong internal links. The themes are consolidated throughout the periods and incorporate new themes with direct and indirect links.

Finally, it is important to highlight that with the arrival of the intelligent and autonomous vehicle, a dynamic is generated that pushes the research in all themes related to ITS.

\section{Conclusions}

This research offers the most extensive analysis of the growth, evolution, and intellectual structure of Intelligent Transportation Systems (ITS) available in the scientific literature. One of the objectives of it is to show the central trends in the ITS research field and to establish a starting point that allows professionals, scientists. and academics to discover strengths or new opportunities for their research areas. In this regard, during the development of the article the main findings were shown, so two general conclusions are presented below: conclusions related to performance field and intellectual structure.

In bibliometric performance terms, the size of the literature related to the ITS research field presented a noticeable growth from 1993 to 2019. Taking into consideration the citations received and the large volume of publications in this research field, it is probable that attention will continue to grow and serve as the framework for other research themes, such as autonomous vehicles, new mobility technologies, and IT technologies. The ITS field presented publications coauthored by 15,428 researchers from 3810 organizations and 108 different countries during the period 1993-2019. Their work was included in 7649 publications with 68128 citations achieved, according to the Web of Science (WoS) Core Collection. The most productive authors were Zhang, Y., Boukerche, A., Zhang, J., Li, X., Onieva, E., Zhang, L., Wang, F. Y., Milanes, V., Perez, J., Wang, X., Wang, Y., Wang, J., Chen, C., Calafate, C. T., Cano, J. C., and Li, Y., and the most cited were Wang, F. Y., Karlaftis, M. G., Milanes, V., Vlahogianni, E. I., Lv, Y. S., Golias, J. C., Li, Z. X., Chen, C., Duan, Y. J., and Kang, W. W. The relationship between the most cited authors and most productive authors revealed the quality and balance of the publications covering the ITS research field.

In this respect, the most productive organizations were the Chinese Academy of Sciences, University of California System, Tsinghua University, Beijing Jiaotong University, State University System of Florida, Tongii University, Shanghai Jiao Tong University, Southeast University China, Institute of Automation CAS, National Chiao Tung University, Indian Institute of Technology System, and University of California at Berkeley.

In a similar vein, the most relevant bibliometric indexes presented an h-index of 106, an indicator that revealed the number of reference documents for its impact on research field development. These publications covered 22,211 citations and had an average of 209.54 citations each. The most relevant authors, with more than one publication within the most cited, were Wang, F. Y., Karlaftis, M. G., Adeli, H., Golias, J. C., Milanes, V., Rilett, L. R., Shladover, S. E., Vlahogianni, E. I., Williams, B. M., Bertozzi, M., Broggi, A., Chabini, I., Cheng, X., Dia, H., Fan, K. C., Fascioli, A., Jiang, X. M., Li, L., Trepanier, M., Yan, G. J., Yang, L. Q., and Zeadally, S. In this respect, the organizations with the most relevant publications were the Chinese Academy of Sciences with 8 publications; University of California System with 7 publications; Massachusetts Institute of Technology, National Technical University of Athens, and University of California at Berkeley with 5 publications each; Institute of Automation CAS, Tsinghua University, and University of Waterloo with 4 publications each; and National University of Defense Technology China, Ohio State University, Shanghai Jiao Tong University, State University System of Florida, University of Montreal, University of Washington and University of Washington, Seattle with 3 publications each. This corresponded with the outcomes obtained initially, which revealed a coherence between the impact of productivity of organizations and authors. 
The most productive countries were leaders in the transport sector, thus their commitment to the research and development of ITS technologies. This does not directly mean that these countries were the first to integrate ITS solutions into their cities. However, keeping these countries in mind will allow them to identify technologies in their initial stages and possible validation of theses.

Another relevant feature of bibliometric analysis is the weight that sources (journals, congresses, and special issues) have in the knowledge dissemination process. In this connection, the most dynamic journals in the ITS research field have gained prestige in the business, scientific, and academic communities, which encourages ITS development and implementation in those fields. It also promotes the development of specialized events that allow the dissemination of the benefits of ITS solutions.

Alternatively, as far as the intellectual structure of the field is concerned, the ITS evolution map provides a complete overview from 1993 to 2019. Bearing it in mind, the main themes (sub-themes) described in the literature were:

ADVANCED-PUBLIC-TRANSPORTATION-SYSTEMS: Neural networks, business intelligence systems, path-planning algorithms, genetic algorithms, constrained programming, GPS-based vehicles, route planning, route choice, real-time traffic data, floating car data, and sustainable transportation.

AUTONOMOUS-VEHICLES-(AVS): Cybercars, automated driving, urban transport, platoon driving, driving assistance, automated highway systems, adaptive control, road vehicle control, power control, intelligent control, fuzzy control, driving assistance, autonomous driving, accident detection, simultaneous localization, information framework, bus rapid transit, self-driving car, path planning, motion planning, and cooperative intersection control.

CONNECTED-VEHICLE: Real-time processing, process synchronization, optimal control, model predictive control, and intersection management.

GEOSPATIAL-INFORMATION-SYSTEM-(GIS): Road preservation, location referencing, transportation sustainability, transportation data, traffic conditions, street network databases, platforms, global positioning systems, environments, urban traffic, traffic route and guidance, and real-time information.

HIGHWAY-AND-ROAD-MANAGEMENT: Control strategies, enhanced observed time difference, transport telematics, signal optimization, road frontage, intersection navigation, intelligent road transportation systems, pollution, kinematic waves, driver assistance systems, highway and road capacity, collision avoidance, video detection, variable speed limit, traffic state estimation, and intelligent vehicles.

INTELLIGENT-VEHICLE: Machine vision, automatic vehicle guidance, wireless communication, truth maintenance system, taxi fleet management, structured data, mobile ad hoc networks, traffic signal control system, traffic light recognition, image recognition, geographic routing, advanced driver assistance system, and driver assistance systems.

NETWORK-MOBILITY: Route optimization, session initiation protocol, mobility management, host identity protocol, and new protocols.

SMART-CITY: video streaming, urban mobility, smart mobility, particle swarm optimization, intelligent transportation, global positioning system, and genetic algorithms.

TRAFFIC-MANAGEMENT: Public and rural transportation, dynamic route guidance, transport telematics, traffic signal control system, traveler information, traffic center, traffic sensors, traffic flow theory, traffic management system, traffic dynamics, road vehicle location, real-time recognition, neural network, new ICT technologies, integrated control, urban sustainable development, optima velocity model, network analysis, and computational intelligence.

TRAFFIC-SIMULATION: Transportation simulation systems, model abstraction method, city logistics, next generation of ATIS, dynamic route guidance, neural network, traffic prediction, network simulation, and genetic algorithm.

VEHICULAR-AD-HOC-NETWORKS: Connectivity, intelligent vehicles, wireless network and communication, vehicle-to-vehicle, vehicle-to-infrastructure, traffic light control, broadcast protocol, 
cooperative positioning, information dissemination, mobility model, authentication protocol, and authentication.

VEHICULAR-COMMUNICATION: wireless network and communication, traffic route and guidance, privacy technique, message authentication, and standard communication.

After analyzing these lines and their evolution, it can be mentioned that the development of ITS technologies will provide support to develop and implement a detailed, long-term, flexible, and integrated ITS strategy with the city's mobility objectives. This will incorporate the user's vision in order to improve the services, know their habits and influence their behavior patterns, and integrate the provision of the service into the various existing means of transport.

It should be highlighted that the ITS research field is developing rapidly, driven mainly by the development of other knowledge fields. In this sense, a second iteration of this analysis can be the identification of areas outside of ITS (e.g., big data, smart cities, smart mobility, algorithms, machine learning, sustainability, new transport business models, new vehicles) that are influencing its growth and consolidation. In addition, the following can be considered research opportunities: determining the most important authors considering the order of authorship, identifying the main collaboration networks, evaluating the relevance of publications according to type, analyzing the main ITS initiatives according to the region or country where they are developed, and analyzing new techniques and methodologies to evaluate the evolution of technology areas, among others.

On the other hand, the definition and deployment of new city models require complementary developments, especially in the research field of Intelligent Transportation Systems, bearing in mind that these determine its configuration, impact, and evolution. In this way, the current research identifies Traffic Management and Communications, Infrastructures and Systems as main thematic areas to consider for urban planning from three vectors: sustainability, "smartization" and dimension. Additionally, the impacts of these thematic areas can be determined, considering the main themes included in these areas and each theme. In this context the advanced public transportation systems, new vehicle technologies (intelligent, connected, and autonomous), smart cities, and ICT technologies are of particular importance. Finally, the discussions and conclusions of this research can be used by universities, research centers, business organizations, and governments to determine the trends in the ITS field, urban planning, and regional development, and to make proper decisions for improving their strategies, investments, and activities.

Author Contributions: Conceptualization, N.K.G.-R., J.M.C.-P., A.L.H.-G., A.M.-B., C.E.G.-T., J.I.G.-T., E.G.-F., H.G.-R. and J.R.L.-R.; methodology, N.K.G.-R., H.G.-R. and J.R.L.-R.; software, N.K.G.-R., H.G.-R. and J.R.L.-R.; validation, N.K.G.-R., H.G.-R. and J.R.L.-R.; formal analysis, N.K.G.-R., J.M.C.-P., A.L.H.-G., A.M.-B., C.E.G.-T., J.I.G.-T., E.G.-F., H.G.-R. and J.R.L.-R.; investigation, N.K.G.-R., J.M.C.-P., A.L.H.-G., A.M.-B., C.E.G.-T., J.I.G.-T., E.G.-F., H.G.-R. and J.R.L.-R.; resources, N.K.G.-R., J.M.C.-P., A.L.H.-G., A.M.-B., C.E.G.-T., J.I.G.-T., E.G.-F., H.G.-R. and J.R.L.-R.; data curation, N.K.G.-R., H.G.-R. and J.R.L.-R.; writing-original draft preparation, N.K.G.-R., H.G.-R. and J.R.L.-R.; writing-review and editing, N.K.G.-R., H.G.-R. and J.R.L.-R.; visualization, N.K.G.-R., J.M.C.-P., A.L.H.-G., A.M.-B., C.E.G.-T., J.I.G.-T., E.G.-F., H.G.-R. and J.R.L.-R.; supervision, N.K.G.-R. and H.G.-R.; project administration, N.K.G.-R. and H.G.-R.; funding acquisition, H.G.-R. All authors have read and agreed to the published version of the manuscript.

Funding: This research received no external funding.

Acknowledgments: The authors acknowledge the support by the CONACYT-Consejo Nacional de Ciencia y Tecnología (Mexico), DGRI-Dirección General de Relaciones Exteriores (Mexico) and COZCYT-Consejo Zacatecano de Ciencia Tecnología e innovación to carry out this research. Additionally, this work has been supported by the Spanish Ministry of Science and Innovation under a grant with reference PID2019-105381GA-I00 (iScience).

Conflicts of Interest: The authors declare no conflict of interest.

\section{Appendix A}


Table A1. H-Classics for the ITS field from 1993 to 2019. This figure shows the citation classics papers identified by means of the H-Classics concept. These publications are considered the main reference base for the ITS field.

\begin{tabular}{|c|c|c|c|}
\hline Rank & Title (Author(s), Year) & Source & $\begin{array}{l}\text { Citations } \\
\text { (Avg) }\end{array}$ \\
\hline 1 & $\begin{array}{l}\text { Traffic Flow Prediction With Big Data: A Deep Learning Approach (Lv, Y.; } \\
\text { Duan, Y.; Kang, W.; Li, Z.; Wang, F. Y. 2015) }\end{array}$ & $\begin{array}{l}\text { IEEE Transactions on Intelligent } \\
\text { Transportation Systems }\end{array}$ & $819(136.50)$ \\
\hline 2 & $\begin{array}{l}\text { Review of road traffic control strategies (Papageorgiou, M.; Diakaki, C.; } \\
\text { Dinopoulou, V.; Kotsialos, A.; Wang, Y. B., 2003) }\end{array}$ & Proceedings of the IEEE & $525(29.17)$ \\
\hline 3 & $\begin{array}{l}\text { Data-Driven Intelligent Transportation Systems: A Survey (Zhang, J.; } \\
\text { Wang, F. Y.; Wang, K.; Lin, W. H.; Xu, X.; Chen, C., 2011) }\end{array}$ & $\begin{array}{l}\text { IEEE Transactions on Intelligent } \\
\text { Transportation Systems }\end{array}$ & $501(50.10)$ \\
\hline 4 & $\begin{array}{l}\text { Intelligent Transportation Systems-Enabling Technologies (Garcia-Ortiz, A.; } \\
\text { Amin, S. M.; Wootton, J. R., 1995) }\end{array}$ & Mathematical and Computer Modelling & $469(0.54)$ \\
\hline 5 & $\begin{array}{l}\text { Modeling and forecasting vehicular traffic flow as a seasonal ARIMA process: } \\
\text { Theoretical basis and empirical results (Williams, B. M.; Hoel, L. A., 2003) }\end{array}$ & Journal of Transportation Engineering & $446(24.78)$ \\
\hline 6 & $\begin{array}{l}\text { Travel-time prediction with support vector regression (Wu, C. H.; Ho, J. M.; } \\
\text { Lee, D. T., 2004) }\end{array}$ & $\begin{array}{l}\text { IEEE Transactions on Intelligent } \\
\text { Transportation Systems }\end{array}$ & $434(25.53)$ \\
\hline 7 & $\begin{array}{l}\text { Connected Vehicles: Solutions and Challenges (Lu, N.; Cheng, N.; Zhang, N.; } \\
\text { Shen, X.; Mark, J. W., 2014) }\end{array}$ & IEEE Internet of Things Journal & $405(57.86)$ \\
\hline 8 & $\begin{array}{l}\text { Vehicular Communication Systems: Enabling Technologies, Applications, } \\
\text { and Future Outlook on Intelligent Transportation (Papadimitratos, P.; } \\
\text { de La Fortelle, A.; Evenssen, K.; Brignolo, R.; Cosenza, S., 2009) }\end{array}$ & IEEE Communications Magazine & $402(33.50)$ \\
\hline 9 & $\begin{array}{l}\text { Smart card data use in public transit: A literature review (Pelletier, M. P.; } \\
\text { Trepanier, M.; Morency, C., 2011) }\end{array}$ & $\begin{array}{l}\text { Transportation Research. Part } \\
\text { C-Emerging Technologies }\end{array}$ & $378(37.80)$ \\
\hline 10 & $\begin{array}{l}\text { A multiagent approach to autonomous intersection management (Dresner, K.; } \\
\text { Stone, P., 2008) }\end{array}$ & Journal of Artificial Intelligence Research & $377(29.00)$ \\
\hline 11 & $\begin{array}{l}\text { Short-term traffic forecasting: Where we are and where we're going } \\
\text { (Vlahogianni, Eleni I.; Karlaftis, Matthew G.; Golias, John C., 2014) }\end{array}$ & $\begin{array}{l}\text { Transportation Research. Part } \\
\text { C-Emerging Technologies }\end{array}$ & $368(52.57)$ \\
\hline 12 & $\begin{array}{l}\text { Parallel Control and Management for Intelligent Transportation Systems: } \\
\text { Concepts, Architectures, and Applications (Wang, F. Y., 2010) }\end{array}$ & $\begin{array}{l}\text { IEEE Transactions on Intelligent } \\
\text { Transportation Systems }\end{array}$ & $365(33.18)$ \\
\hline
\end{tabular}


Table A1. Cont.

\begin{tabular}{|c|c|c|c|}
\hline Rank & Title (Author(s), Year) & Source & $\begin{array}{l}\text { Citations } \\
\text { (Avg) }\end{array}$ \\
\hline 13 & $\begin{array}{l}\text { Estimating vehicle fuel consumption and emissions based on instantaneous } \\
\text { speed and acceleration levels (Ahn, K.; Rakha, H.; Trani, A.; } \\
\text { Van Aerde, M., 2002) }\end{array}$ & Journal of Transportation Engineering & $357(18.79)$ \\
\hline 14 & $\begin{array}{l}\text { A survey on vehicular cloud computing (Whaiduzzaman, M. D.; Sookhak, M.; } \\
\text { Gani, A.; Buyya, R., 2014) }\end{array}$ & $\begin{array}{l}\text { Journal of Network and } \\
\text { Computer Applications }\end{array}$ & $353(50.43)$ \\
\hline 15 & $\begin{array}{l}\text { Optimized and meta-optimized neural networks for short-term traffic flow } \\
\text { prediction: A genetic approach (Vlahogianni, E. I.; Karlaftis, M. G.; } \\
\text { Golias, J. C., 2005) }\end{array}$ & $\begin{array}{l}\text { Transportation Research. Part } \\
\text { C-Emerging Technologies }\end{array}$ & $331(20.69)$ \\
\hline 16 & $\begin{array}{l}\text { Real-Time Urban Monitoring Using Cell Phones: A Case Study in Rome } \\
\text { (Calabrese, F.; Colonna, M.; Lovisolo, P.; Parata, D.; Ratti, C., 2011) }\end{array}$ & $\begin{array}{l}\text { IEEE Transactions on Intelligent } \\
\text { Transportation Systems }\end{array}$ & $311(31.10)$ \\
\hline 17 & $\begin{array}{l}\text { Deep Architecture for Traffic Flow Prediction: Deep Belief Networks With } \\
\text { Multitask Learning (Huang, W.; Song, G.; Hong, H.; Xie, K., 2014) }\end{array}$ & $\begin{array}{l}\text { IEEE Transactions on Intelligent } \\
\text { Transportation Systems }\end{array}$ & $311(44.43)$ \\
\hline 18 & $\begin{array}{l}\text { A license plate-recognition algorithm for intelligent transportation system } \\
\text { applications (Anagnostopoulos, C. N. E.; Anagnostopoulos, I. E.; Loumos, V.; } \\
\text { Kayafas, E., 2006) }\end{array}$ & $\begin{array}{l}\text { IEEE Transactions on Intelligent } \\
\text { Transportation Systems }\end{array}$ & $302(20.13)$ \\
\hline 19 & $\begin{array}{l}\text { Traffic flow forecasting: Comparison of modeling approaches (Smith, B. L.; } \\
\text { Demetsky, M. J., 1997) }\end{array}$ & $\begin{array}{l}\text { Journal of Transportation } \\
\text { Engineering-ASCE }\end{array}$ & $299(12.46)$ \\
\hline 20 & $\begin{array}{l}\text { Cooperative Adaptive Cruise Control in Real Traffic Situations (Milanes, V.; } \\
\text { Shladover, S. E.; Spring, J.; Nowakowski, C.; Kawazoe, H.; } \\
\text { Nakamura, M., 2014) }\end{array}$ & $\begin{array}{l}\text { IEEE Transactions on Intelligent } \\
\text { Transportation Systems }\end{array}$ & $294(42.00)$ \\
\hline 21 & $\begin{array}{l}\text { Stabilization effect of traffic flow in an extended car-following model based on } \\
\text { an intelligent transportation system application (Ge, H. X.; Dai, S. Q.; } \\
\text { Dong, L. Y.; Xue, Y., 2004) }\end{array}$ & Physical Review E & $285(16.76)$ \\
\hline 22 & $\begin{array}{l}\text { Short-term traffic forecasting: Overview of objectives and methods } \\
\text { (Vlahogianni, E. I.; Golias, J. C.; Karlaftis, M. G., 2004) }\end{array}$ & Transport Reviews & $285(16.76)$ \\
\hline 23 & $\begin{array}{l}\text { Challenges of intervehicle ad hoc networks (Blum, J. J.; Eskandarian, A.; } \\
\text { Hoffman, L. J., 2004) }\end{array}$ & $\begin{array}{l}\text { IEEE Transactions on Intelligent } \\
\text { Transportation Systems }\end{array}$ & $279(16.41)$ \\
\hline 24 & Robust lane detection and tracking in challenging scenarios (Kim, Z. W., 2008) & $\begin{array}{l}\text { IEEE Transactions on Intelligent } \\
\text { Transportation Systems }\end{array}$ & $276(21.23)$ \\
\hline
\end{tabular}


Table A1. Cont.

\begin{tabular}{|c|c|c|c|}
\hline Rank & Title (Author(s), Year) & Source & $\begin{array}{l}\text { Citations } \\
\text { (Avg) }\end{array}$ \\
\hline 25 & $\begin{array}{l}\text { A multivariate state space approach for urban traffic flow modeling and } \\
\text { prediction (Stathopoulos, A.; Karlaftis, M. G., 2003) }\end{array}$ & $\begin{array}{l}\text { Transportation Research. Part } \\
\text { C-Emerging Technologies }\end{array}$ & $274(15.22)$ \\
\hline 26 & $\begin{array}{l}\text { A Review of the Applications of Agent Technology in Traffic and } \\
\text { Transportation Systems (Chen, B.; Cheng, H. H., 2010) }\end{array}$ & $\begin{array}{l}\text { IEEE Transactions on Intelligent } \\
\text { Transportation Systems }\end{array}$ & $269(24.45)$ \\
\hline 27 & $\begin{array}{l}\text { Development and Evaluation of a Cooperative Vehicle Intersection Control } \\
\text { Algorithm Under the Connected Vehicles Environment (Lee, J.; Park, B., 2012) }\end{array}$ & $\begin{array}{l}\text { IEEE Transactions on Intelligent } \\
\text { Transportation Systems }\end{array}$ & $264(29.33)$ \\
\hline 28 & WAVE: A Tutorial (Uzcategui, R. A.; Acosta-Marum, G., 2009) & IEEE Communications Magazine & $250(20.83)$ \\
\hline 29 & $\begin{array}{l}\text { Smart Antennas in Intelligent Transportation Systems (Li, M.; Wang, B.; Lu, Y.; } \\
\text { Zhou, M. T.; Chen, I. M., 2010) }\end{array}$ & $\begin{array}{l}\text { Wireless Technologies in Intelligent } \\
\text { Transportation Systems }\end{array}$ & $250(22.73)$ \\
\hline 30 & $\begin{array}{l}\text { Vehicular Ad hoc Networks (VANETs): Challenges and perspectives } \\
\text { (Yousefi, S.; Mousavi, M. S.; Fathy, M., 2006) }\end{array}$ & $\begin{array}{l}2006 \text { 6th International Conference on ITS } \\
\text { Telecommunications. Proceedings }\end{array}$ & $246(16.40)$ \\
\hline 31 & $\begin{array}{l}\text { Energy and emissions impacts of a freeway-based dynamic eco-driving } \\
\text { system (Barth, M.; Boriboonsomsin, K., 2009) }\end{array}$ & $\begin{array}{l}\text { Transportation Research. Part D-Transport } \\
\text { and Environment }\end{array}$ & $243(20.25)$ \\
\hline 32 & $\begin{array}{l}\text { Online-SVR for short-term traffic flow prediction under typical and atypical } \\
\text { traffic conditions (Castro-Neto, M.; Jeong, Y. S.; Jeong, M. K.; Han, L. D., 2009) }\end{array}$ & Expert Systems with Applications & $242(20.17)$ \\
\hline 33 & $\begin{array}{l}\text { Vision-based intelligent vehicles: State of the art and perspectives } \\
\text { (Bertozzi, M.; Broggi, A.; Fascioli, A., 2000) }\end{array}$ & Robotics and Autonomous Systems & $238(11.33)$ \\
\hline 34 & $\begin{array}{l}\text { LSTM network: a deep learning approach for short-term traffic forecast } \\
\text { (Zhao, Z.; Chen, W.; Wu, X.; Chen, P. C. Y.; Liu, J., 2017) }\end{array}$ & IET Intelligent Transport Systems & $238(59.50)$ \\
\hline 35 & $\begin{array}{l}\text { Developing Vehicular Data Cloud Services in the IoT Environment (He, W.; } \\
\text { Yan, G.; Xu, Li D., 2014) }\end{array}$ & IEEE Transactions on Industrial Informatics & $230(32.86)$ \\
\hline 36 & $\begin{array}{l}\text { A Survey of Inter-Vehicle Communication Protocols and Their Applications } \\
\text { (Willke, T. L.; Tientrakool, P.; Maxemchuk, N. F., 2009) }\end{array}$ & $\begin{array}{l}\text { IEEE Communications Surveys } \\
\text { and Tutorials }\end{array}$ & $228(19.00)$ \\
\hline 37 & $\begin{array}{l}\text { Last mile distribution in humanitarian relief (Balcik, B.; Beamon, B. M.; } \\
\text { Smilowitz, K., 2008) }\end{array}$ & Journal of Intelligent Transportation Systems & $221(17.00)$ \\
\hline 38 & $\begin{array}{l}\text { Dynamic wavelet neural network model for traffic flow forecasting } \\
\text { (Jiang, X. M.; Adeli, H., 2005) }\end{array}$ & Journal of Transportation Engineering & $219(13.69)$ \\
\hline
\end{tabular}


Table A1. Cont.

\begin{tabular}{|c|c|c|c|}
\hline Rank & Title (Author(s), Year) & Source & $\begin{array}{l}\text { Citations } \\
\text { (Avg) }\end{array}$ \\
\hline 39 & $\begin{array}{l}\text { Short-term freeway traffic flow prediction: Bayesian combined neural network } \\
\text { approach (Zheng, W. Z.; Lee, D. H.; Shi, Q. X., 2006) }\end{array}$ & Journal of Transportation Engineering & $218(14.53)$ \\
\hline 40 & $\begin{array}{l}\text { Trip-Based Optimal Power Management of Plug-in Hybrid Electric Vehicles } \\
\text { (Gong, Q.; Li, Y.; Peng, Z. R., 2008) }\end{array}$ & IEEE Transactions on Vehicular Technology & $217(16.69)$ \\
\hline 41 & $\begin{array}{l}\text { Traffic sign recognition and analysis for intelligent vehicles (de la Escalera, A.; } \\
\text { Armingol, J. M.; Mata, M., 2003) }\end{array}$ & Image And Vision Computing & $216(12.00)$ \\
\hline 42 & $\begin{array}{l}\text { Toward Cloud-Based Vehicular Networks with Efficient Resource } \\
\text { Management (Yu, R.; Zhang, Y.; Gjessing, S.; Xia, W.; Yang, K., 2013) }\end{array}$ & IEEE Network & $212(26.50)$ \\
\hline 43 & $\begin{array}{l}\text { D2D for Intelligent Transportation Systems: A Feasibility Study (Cheng, X.; } \\
\text { Yang, L.; Shen, X., 2015) }\end{array}$ & $\begin{array}{l}\text { IEEE Transactions on Intelligent } \\
\text { Transportation Systems }\end{array}$ & $211(35.17)$ \\
\hline 44 & $\begin{array}{l}\text { Heterogeneous Vehicular Networking: A Survey on Architecture, Challenges, } \\
\text { and Solutions (Zheng, K.; Zheng, Q.; Chatzimisios, P.; Xiang, W.; } \\
\text { Zhou, Y., 2015) }\end{array}$ & $\begin{array}{l}\text { IEEE Communications Surveys } \\
\text { and Tutorials }\end{array}$ & $208(34.67)$ \\
\hline 45 & $\begin{array}{l}\text { Energy Management in Plug-in Hybrid Electric Vehicles: Recent Progress and } \\
\text { a Connected Vehicles Perspective (Martinez, C. M.; Hu, X.; Cao, D.; Velenis, E.; } \\
\text { Gao, B.; Wellers, M., 2017) }\end{array}$ & IEEE Transactions on Vehicular Technology & $203(50.75)$ \\
\hline 46 & $\begin{array}{l}\text { Vehicle-to-Vehicle Channel Modeling and Measurements: Recent Advances } \\
\text { and Future Challenges (Wang, C. X.; Cheng, X.; Laurenson, D. I., 2009) }\end{array}$ & IEEE Communications Magazine & $201(16.75)$ \\
\hline 47 & $\begin{array}{l}\text { An object-oriented neural network approach to short-term traffic forecasting } \\
\text { (Dia, H., 2001) }\end{array}$ & European Journal of Operational Research & $200(10.00)$ \\
\hline 48 & $\begin{array}{l}\text { A Review of Motion Planning Techniques for Automated Vehicles } \\
\text { (Gonzalez, D.; Perez, J.; Milanes, V.; Nashashibi, F., 2016) }\end{array}$ & $\begin{array}{l}\text { IEEE Transactions on Intelligent } \\
\text { Transportation Systems }\end{array}$ & $198(39.6)$ \\
\hline 49 & $\begin{array}{l}\text { Data fusion in intelligent transportation systems: Progress and } \\
\text { challenges-A survey (El Faouzi, N. E.; Leung, H.; Kurian, A., 2011) }\end{array}$ & Information Fusion & $191(19.1)$ \\
\hline 50 & $\begin{array}{l}\text { An agent-based approach to modelling driver route choice behaviour under } \\
\text { the influence of real-time information (Dia, H., 2002) }\end{array}$ & $\begin{array}{l}\text { Transportation Research. Part } \\
\text { C-Emerging Technologies }\end{array}$ & $179(9.42)$ \\
\hline 51 & $\begin{array}{l}\text { Survey on VANET security challenges and possible cryptographic solutions } \\
\text { (Mejri, M. N.; Ben-Othman, J.; Hamdi, M., 2014) }\end{array}$ & Vehicular Communications & $177(25.29)$ \\
\hline
\end{tabular}


Table A1. Cont.

\begin{tabular}{|c|c|c|c|}
\hline Rank & Title (Author(s), Year) & Source & $\begin{array}{l}\text { Citations } \\
\text { (Avg) }\end{array}$ \\
\hline 52 & $\begin{array}{l}\text { Short-Term Traffic Flow Forecasting: An Experimental Comparison of } \\
\text { Time-Series Analysis and Supervised Learning (Lippi, M.; Bertini, M.; } \\
\text { Frasconi, P., 2013) }\end{array}$ & $\begin{array}{l}\text { IEEE Transactions on Intelligent } \\
\text { Transportation Systems }\end{array}$ & $176(22.00)$ \\
\hline 53 & $\begin{array}{l}\text { Predicting Taxi-Passenger Demand Using Streaming Data (Moreira-Matias, L.; } \\
\text { Gama, J.; Ferreira, M.; Mendes-Moreira, J.; Damas, L., 2013) }\end{array}$ & $\begin{array}{l}\text { IEEE Transactions on Intelligent } \\
\text { Transportation Systems }\end{array}$ & $170(21.25)$ \\
\hline 54 & $\begin{array}{l}\text { On the accuracy of cellular mobile station location estimation } \\
\text { (Spirito, M. A., 2001) }\end{array}$ & IEEE Transactions on Vehicular Technology & $169(8.45)$ \\
\hline 55 & Potential Cyberattacks on Automated Vehicles (Petit, J.; Shladover, S. E., 2015) & $\begin{array}{l}\text { IEEE Transactions on Intelligent } \\
\text { Transportation Systems }\end{array}$ & $169(28.17)$ \\
\hline 56 & $\begin{array}{l}\text { Multivariate vehicular traffic flow prediction-Evaluation of ARIMAX } \\
\text { modeling (Williams, B. M., 2001) }\end{array}$ & $\begin{array}{l}\text { Traffic Flow Theory and Highway Capacity } \\
\text { 2001: Highway Operations, Capacity, } \\
\text { and Traffic Control }\end{array}$ & $163(8.15)$ \\
\hline 57 & $\begin{array}{l}\text { UAV-Enabled Intelligent Transportation Systems for the Smart City: } \\
\text { Applications and Challenges (Menouar, H.; Guvenc, I.; Akkaya, K.; } \\
\text { Uluagac, A. S.; Kadri, A.; Tuncer, A., 2017) }\end{array}$ & IEEE Communications Magazine & $163(40.75)$ \\
\hline 58 & $\begin{array}{l}\text { Real-time multivehicle truckload pickup and delivery problems (Yang, J.; } \\
\text { Jaillet, P.; Mahmassani, H., 2004) }\end{array}$ & Transportation Science & $161(9.47)$ \\
\hline 59 & $\begin{array}{l}\text { Intelligent Transportation Systems (Dimitrakopoulos, G.; } \\
\text { Demestichas, P., 2010) }\end{array}$ & IEEE Vehicular Technology Magazine & $161(14.64)$ \\
\hline 60 & $\begin{array}{l}\text { Expected shortest paths in dynamic and stochastic traffic networks (Fu, L. P.; } \\
\text { Rilett, L. R., 1998) }\end{array}$ & $\begin{array}{l}\text { Transportation Research. Part } \\
\text { B-Methodological }\end{array}$ & $158(6.87)$ \\
\hline 61 & $\begin{array}{l}\text { Distributed Consensus Strategy for Platooning of Vehicles in the Presence of } \\
\text { Time-Varying Heterogeneous Communication Delays (di Bernardo, M.; } \\
\text { Salvi, A.; Santini, S., 2015) }\end{array}$ & $\begin{array}{l}\text { IEEE Transactions on Intelligent } \\
\text { Transportation Systems }\end{array}$ & $158(26.33)$ \\
\hline 62 & $\begin{array}{l}\text { Modeling cooperative and autonomous adaptive cruise control dynamic } \\
\text { responses using experimental data (Milanes, V.; Shladover, S. E., 2014) }\end{array}$ & $\begin{array}{l}\text { Transportation Research. Part } \\
\text { C-Emerging Technologies }\end{array}$ & $152(21.71)$ \\
\hline 63 & $\begin{array}{l}\text { Vehicular communication ad hoc routing protocols: A survey (Sharef, B. T.; } \\
\text { Alsaqour, R. A.; Ismail, M., 2014) }\end{array}$ & $\begin{array}{l}\text { Journal of Network And } \\
\text { Computer Applications }\end{array}$ & $152(21.71)$ \\
\hline
\end{tabular}


Table A1. Cont.

\begin{tabular}{|c|c|c|c|}
\hline Rank & Title (Author(s), Year) & Source & $\begin{array}{l}\text { Citations } \\
\text { (Avg) }\end{array}$ \\
\hline 64 & $\begin{array}{l}\text { Adaptive Kalman filter approach for stochastic short-term traffic flow rate } \\
\text { prediction and uncertainty quantification (Guo, J.; Huang, W.; } \\
\text { Williams, B. M., 2014) }\end{array}$ & $\begin{array}{l}\text { Transportation Research. Part } \\
\text { C-Emerging Technologies }\end{array}$ & $148(21.14)$ \\
\hline 65 & $\begin{array}{l}\text { On-demand high-capacity ride-sharing via dynamic trip-vehicle assignment } \\
\text { (Alonso-Mora, J.; Samaranayake, S.; Wallar, A.; Frazzoli, E.; Rus, D., 2017) }\end{array}$ & $\begin{array}{l}\text { Proceedings of The National Academy of } \\
\text { Sciences of the United States of America }\end{array}$ & $146(36.50)$ \\
\hline 66 & $\begin{array}{l}\text { A simple and effective method for predicting travel times on freeways (Rice, J.; } \\
\text { van Zwet, E., 2004) }\end{array}$ & $\begin{array}{l}\text { IEEE Transactions on Intelligent } \\
\text { Transportation Systems }\end{array}$ & $145(8.53)$ \\
\hline 67 & $\begin{array}{l}\text { Enhancing VANET Performance by Joint Adaptation of Transmission Power } \\
\text { and Contention Window Size (Rawat, D. B.; Popescu, D. C.; Yan, G.; } \\
\text { Olariu, S., 2011) }\end{array}$ & $\begin{array}{l}\text { IEEE Transactions on Parallel and } \\
\text { Distributed Systems }\end{array}$ & $144(14.40)$ \\
\hline 68 & $\begin{array}{l}\text { Reinforcement learning for True Adaptive traffic signal control (Abdulhai, B.; } \\
\text { Pringle, R.; Karakoulas, G. J., 2003) }\end{array}$ & Journal of Transportation Engineering & $143(7.94)$ \\
\hline 69 & $\begin{array}{l}\text { Individual trip destination estimation in a transit Smart Card Automated Fare } \\
\text { Collection system (Trepanier, M.; Tranchant, N.; Chapleau, R., 2007) }\end{array}$ & Journal of Intelligent Transportation Systems & $143(10.21)$ \\
\hline 70 & $\begin{array}{l}\text { Towards the development of Intelligent Transportation Systems } \\
\text { (Figueiredo, L.; Jesus, I.; Machado, J. A. T.; Ferreira, J. R.; } \\
\text { de Carvalho, J. L. M., 2001) }\end{array}$ & $\begin{array}{l}2001 \text { IEEE Intelligent Transportation } \\
\text { Systems-Proceedings }\end{array}$ & $140(7.00)$ \\
\hline 71 & $\begin{array}{l}\text { Wavelet packet-autocorrelation function method for traffic flow pattern } \\
\text { analysis (Jiang, X. M.; Adeli, H., 2004) }\end{array}$ & $\begin{array}{l}\text { Computer-Aided Civil And } \\
\text { Infrastructure Engineering }\end{array}$ & $139(8.18)$ \\
\hline 72 & $\begin{array}{l}\text { Interworking of DSRC and Cellular Network Technologies for V2X } \\
\text { Communications: A Survey (Abboud, K.; Omar, H. A.; Zhuang, W., 2016) }\end{array}$ & IEEE Transactions on Vehicular Technology & $139(27.80)$ \\
\hline 73 & $\begin{array}{l}\text { Statistical analysis of accident severity on rural freeways (Shankar, V.; } \\
\text { Mannering, F.; Barfield, W., 1996) }\end{array}$ & Accident Analysis and Prevention & $137(5.48)$ \\
\hline 74 & $\begin{array}{l}\text { Spectral basis neural networks for real-time travel time forecasting (Park, D.; } \\
\text { Rilett, L. R.; Han, G., 1999) }\end{array}$ & Journal of Transportation Engineering & $135(6.14)$ \\
\hline 75 & $\begin{array}{l}\text { Artificial vision in road vehicles (Bertozzi, M.; Broggi, A.; Cellario, M.; } \\
\text { Fascioli, A.; Lombardi, P.; Porta, M., 2002) }\end{array}$ & Proceedings of the IEEE & $133(7.00)$ \\
\hline
\end{tabular}


Table A1. Cont.

\begin{tabular}{|c|c|c|c|}
\hline Rank & Title (Author(s), Year) & Source & $\begin{array}{l}\text { Citations } \\
\text { (Avg) }\end{array}$ \\
\hline 76 & $\begin{array}{l}\text { Dynamic travel time prediction with real-time and historic data (Chien, S. I. J.; } \\
\text { Kuchipudi, C. M., 2003) }\end{array}$ & Journal of Transportation Engineering & $133(7.39)$ \\
\hline 77 & $\begin{array}{l}\text { National review of hurricane evacuation plans and policies: a comparison and } \\
\text { contrast of state practices (Urbina, E.; Wolshon, B., 2003) }\end{array}$ & $\begin{array}{l}\text { Transportation Research. Part A-Policy } \\
\text { and Practice }\end{array}$ & $131(7.28)$ \\
\hline 78 & $\begin{array}{l}\text { An Algorithm for License Plate Recognition Applied to Intelligent } \\
\text { Transportation System (Wen, Y.; Lu, Y.; Yan, J.; Zhou, Z.; von Deneen, K. M.; } \\
\text { Shi, P., 2011) }\end{array}$ & $\begin{array}{l}\text { IEEE Transactions on Intelligent } \\
\text { Transportation Systems }\end{array}$ & $131(13.10)$ \\
\hline 79 & $\begin{array}{l}\text { Heuristic shortest path algorithms for transportation applications: State of the } \\
\text { art (Fu, L.; Sun, D.; Rilett, L. R., 2006) }\end{array}$ & Computers $\mathcal{E}$ Operations Research & $128(8.53)$ \\
\hline 80 & $\begin{array}{l}\text { MAC for dedicated short range communications in intelligent transport } \\
\text { system (Zhu, J.; Roy, S., 2003) }\end{array}$ & IEEE Communications Magazine & $127(7.06)$ \\
\hline 81 & $\begin{array}{l}\text { Vehicle detection using normalized color and edge map (Tsai, L. W.; } \\
\text { Hsieh, J. W.; Fan, K. C., 2007) }\end{array}$ & IEEE Transactions on Image Processing & $127(9.07)$ \\
\hline 82 & $\begin{array}{l}\text { Lane detection with moving vehicles in the traffic scenes (Cheng, H. Y.; } \\
\text { Jeng, B. S.; Tseng, P. T.; Fan, K. C., 2006) }\end{array}$ & $\begin{array}{l}\text { IEEE Transactions on Intelligent } \\
\text { Transportation Systems }\end{array}$ & $124(8.27)$ \\
\hline 83 & $\begin{array}{l}\text { On the Ability of the } 802.11 \text { p MAC Method and STDMA to Support Real-Time } \\
\text { Vehicle-to-Vehicle Communication (Bilstrup, K.; Uhlemann, Ek; Strom, Ek G.; } \\
\text { Bilstrup, U., 2009) }\end{array}$ & $\begin{array}{l}\text { Eurasip Journal on Wireless } \\
\text { Communications and Networking }\end{array}$ & $124(10.33)$ \\
\hline 84 & $\begin{array}{l}\text { Traffic Sign Recognition With Hinge Loss Trained Convolutional Neural } \\
\text { Networks (Jin, J.; Fu, K.; Zhang, C., 2014) }\end{array}$ & $\begin{array}{l}\text { IEEE Transactions on Intelligent } \\
\text { Transportation Systems }\end{array}$ & $122(17.43)$ \\
\hline 85 & $\begin{array}{l}\text { Neural network model for rapid forecasting of freeway link travel time } \\
\text { (Dharia, A.; Adeli, H., 2003) }\end{array}$ & $\begin{array}{l}\text { Engineering Applications of } \\
\text { Artificial Intelligence }\end{array}$ & $121(6.72)$ \\
\hline 86 & $\begin{array}{l}\text { Decomposition and decoupling effects of carbon dioxide emission from } \\
\text { highway transportation in Taiwan, Germany, Japan and South Korea (Lu, I. J.; } \\
\text { Lin, S. J.; Lewis, C., 2007) }\end{array}$ & Energy Policy & $120(8.57)$ \\
\hline 87 & $\begin{array}{l}\text { Intelligent freight-transportation systems: Assessment and the contribution of } \\
\text { operations research (Crainic, T. G.; Gendreau, M.; Potvin, J. Y., 2009) }\end{array}$ & $\begin{array}{l}\text { Transportation Research. Part } \\
\text { C-Emerging Technologies }\end{array}$ & $120(10.00)$ \\
\hline 88 & $\begin{array}{l}\text { Information centric services in Smart Cities (Piro, G.; Cianci, I.; Grieco, L. A.; } \\
\text { Boggia, G.; Camarda, P., 2014) }\end{array}$ & Journal Of Systems and Software & $120(17.14)$ \\
\hline
\end{tabular}


Table A1. Cont.

\begin{tabular}{|c|c|c|c|}
\hline Rank & Title (Author(s), Year) & Source & $\begin{array}{l}\text { Citations } \\
\text { (Avg) }\end{array}$ \\
\hline 89 & $\begin{array}{l}\text { Safety Benefits of Forward Collision Warning, Brake Assist, and Autonomous } \\
\text { Braking Systems in Rear-End Collisions (Kusano, K. D.; Gabler, H. C., 2012) }\end{array}$ & $\begin{array}{l}\text { IEEE Transactions on Intelligent } \\
\text { Transportation Systems }\end{array}$ & $117(13.00)$ \\
\hline 90 & $\begin{array}{l}\text { Integration Challenges of Intelligent Transportation Systems with Connected } \\
\text { Vehicle, Cloud Computing, and Internet of Things Technologies } \\
\text { (Guerrero-Ibanez, J. A; Zeadally, S.; Contreras-Castillo, J., 2015) }\end{array}$ & IEEE Wireless Communications & $115(19.17)$ \\
\hline 91 & $\begin{array}{l}\text { Toward the design of intelligent traveler information systems (Adler, J. L.; } \\
\text { Blue, V. J., 1998) }\end{array}$ & $\begin{array}{l}\text { Transportation Research. Part } \\
\text { C-Emerging Technologies }\end{array}$ & $114(4.96)$ \\
\hline 92 & $\begin{array}{l}\text { Discrete dynamic shortest path problems in transportation } \\
\text { applications-Complexity and algorithms with optimal run time } \\
\text { (Chabini, I., 1998) }\end{array}$ & $\begin{array}{l}\text { Forecasting, Travel Behavior, } \\
\text { and Network Modeling }\end{array}$ & $113(4.91)$ \\
\hline 93 & $\begin{array}{l}\text { Planning roadside infrastructure for information dissemination in intelligent } \\
\text { transportation systems (Trullols, O.; Fiore, M.; Casetti, C.; Chiasserini, C. F.; } \\
\text { Barcelo Ordinas, J. M., 2010) }\end{array}$ & Computer Communications & $112(10.18)$ \\
\hline 94 & $\begin{array}{l}\text { A Survey of Traffic Control With Vehicular Communications (Li, L.; Wen, D.; } \\
\text { Yao, D., 2014) }\end{array}$ & $\begin{array}{l}\text { IEEE Transactions on Intelligent } \\
\text { Transportation Systems }\end{array}$ & $112(16.00)$ \\
\hline 95 & $\begin{array}{l}\text { Estimating magnitude and duration of incident delays (Garib, A.; } \\
\text { Radwan, A. E.; AlDeek, H., 1997) }\end{array}$ & $\begin{array}{l}\text { Journal of Transportation } \\
\text { Engineering-ASCE }\end{array}$ & $111(4.63)$ \\
\hline 96 & $\begin{array}{l}\text { Efficient missing data imputing for traffic flow by considering temporal and } \\
\text { spatial dependence (Li, L.; Li, Y.; Li, Z., 2013) }\end{array}$ & $\begin{array}{l}\text { Transportation Research. Part } \\
\text { C-Emerging Technologies }\end{array}$ & $111(13.88)$ \\
\hline 97 & $\begin{array}{l}\text { Adaptations of the } \mathrm{A}^{*} \text { algorithm for the computation of fastest paths in } \\
\text { deterministic discrete-time dynamic networks (Chabini, I.; Lan, S., 2002) }\end{array}$ & $\begin{array}{l}\text { IEEE Transactions on Intelligent } \\
\text { Transportation Systems }\end{array}$ & $110(5.79)$ \\
\hline 98 & $\begin{array}{l}\text { Wireless sensor networks in intelligent transportation systems (Tubaishat, M.; } \\
\text { Zhuang, P.; Qi, Q.; Shang, Y., 2009) }\end{array}$ & $\begin{array}{l}\text { Wireless Communications } \mathcal{E} \\
\text { Mobile Computing }\end{array}$ & $110(9.17)$ \\
\hline 99 & $\begin{array}{l}\text { Vanet-Cloud: A Generic Cloud Computing Model for Vehicular Ad hoc } \\
\text { Networks (Bitam, S.; Mellouk, A.; Zeadally, S., 2015) }\end{array}$ & IEEE Wireless Communications & $110(18.33)$ \\
\hline 100 & $\begin{array}{l}\text { Intelligent transportation system based dynamic vehicle routing and } \\
\text { scheduling with variable travel times (Taniguchi, E.; Shimamoto, H., 2004) }\end{array}$ & $\begin{array}{l}\text { Transportation Research. Part } \\
\text { C-Emerging Technologies }\end{array}$ & $109(6.41)$ \\
\hline
\end{tabular}


Table A1. Cont.

\begin{tabular}{cllc}
\hline Rank & \multicolumn{1}{c}{ Title (Author(s), Year) } & \multicolumn{1}{c}{$\begin{array}{c}\text { Citations } \\
\text { (Avg) }\end{array}$} \\
\hline 101 & $\begin{array}{l}\text { Commuters route choice behaviour (Selten, R.; Chmura, T.; Pitz, T.; Kube, S.; } \\
\text { Schreckenberg, M., 2007) }\end{array}$ & Games and Economic Behavior \\
\hline 102 & $\begin{array}{l}\text { Towards Blockchain-based Intelligent Transportation Systems (Yuan, Y.; } \\
\text { Wang, F. Y., 2016) }\end{array}$ & $\begin{array}{l}\text { 2016 IEEE 19th International Conference on } \\
\text { Intelligent Transportation Systems (ITSC) }\end{array}$ & 109 (21.80) \\
\hline 103 & $\begin{array}{l}\text { Intelligent Transportation Spaces: Vehicles, Traffic, Communications, } \\
\text { and Beyond (Qu, F.; Wang, F. Y.; Yang, L., 2010) }\end{array}$ & IEEE Communications Magazine \\
\hline 104 & $\begin{array}{l}\text { Routing Protocols in Vehicular Ad Hoc Networks: A Survey and Future } \\
\text { Perspectives (Lin, Y. W.; Chen, Y. S.; Lee, S. L., 2010) }\end{array}$ & $\begin{array}{l}\text { Journal of Information Science } \\
\text { and Engineering }\end{array}$ \\
\hline 105 & $\begin{array}{l}\text { Automatic Road Crack Detection Using Random Structured Forests (Shi, Y.; } \\
\text { Cui, L.; Qi, Z.; Meng, F.; Chen, Z., 2016) }\end{array}$ & $\begin{array}{l}\text { IEEE Transactions on Intelligent } \\
\text { Transportation Systems }\end{array}$ \\
\hline 106 & $\begin{array}{l}\text { Blockchain-Based Dynamic Key Management for Heterogeneous Intelligent } \\
\text { Transportation Systems (Lei, A.; Cruickshank, H.; Cao, Y.; Asuquo, P.; } \\
\text { Ogah, C. P. A.; Sun, Z., 2017) }\end{array}$ & IEEE Internet of Things Journal \\
\hline
\end{tabular}




\section{References}

1. Lah, O.; Kodukula, S.; Shrestha, S. Transition to Sustainable Mobility: Pathways, Policies, Co-Benefits and Opportunities of Low Carbon Transport Future; Academic Press: Hanoi, Viet Nam, 2019.

2. Bakogiannis, E.; Kyriakidis, C.; Siti, M.; Eleftheriou, V. Four stories for sustainable mobility in Greece. Transp. Res. Procedia 2017, 24, 345-353. [CrossRef]

3. Xiong, Z.; Sheng, H.; Rong, W.G.; Cooper, D.E. Intelligent transportation systems for smart cities: A progress review. Sci. China-Inf. Sci. 2012, 55, 2908-2914. [CrossRef]

4. Scoffham, E.; Vale, B. How compact is sustainable-How sustainable is compact. In Compact City: A Sustain. Urban from? Spon Press: Oxford, United Kingdom, 1996; pp. 66-73.

5. Zhu, F.; Li, Z.; Chen, S.; Xiong, G. Parallel transportation management and control system and its applications in building smart cities. IEEE Trans. Intell. Transp. Syst. 2016, 17, 1576-1585. [CrossRef]

6. d'Orey, P.M.; Ferreira, M. ITS for sustainable mobility: A survey on applications and impact assessment tools. IEEE Trans. Intell. Transp. Syst. 2014, 15, 477-493. [CrossRef]

7. Dey, K.C.; Mishra, A.; Chowdhury, M. Potential of intelligent transportation systems in mitigating adverse weather impacts on road mobility: A review. IEEE Trans. Intell. Transp. Syst. 2015, 16, 1107-1119. [CrossRef]

8. Al-Sultan, S.; Al-Bayatti, A.H.; Zedan, H. Context-aware driver behavior detection system in intelligent transportation systems. IEEE Trans. Veh. Technol. 2013, 62, 4264-4275. [CrossRef]

9. Furstenau, L.B.; Sott, M.K.; Homrich, A.J.O.; Kipper, L.M.; Al Abri, A.A.; Cardoso, T.F.; López-Robles, J.R.; Cobo, M.J. 20 Years of Scientific Evolution of Cyber Security: A Science Mapping. In Proceedings of the International Conference on Industrial Engineering and Operations Management, Dubai, UAE, 10-12 March 2020.

10. Grant-Muller, S.; Usher, M. Intelligent Transport Systems: The propensity for environmental and economic benefits. Technol. Soc. Chang 2014, 82, 149-166. [CrossRef]

11. Balasubramaniam, A.; Paul, A.; Hong, W.H.; Seo, H.; Kim, J.H. Comparative Analysis of Intelligent Transportation Systems for Sustainable Environment in Smart Cities. Sustainability 2017, 9, 1120. [CrossRef]

12. Kala, R. Intelligent Transportation Systems with Diverse Vehicles; Burlington: Oxford, United Kingdom, 2016; pp. 420-458.

13. Singh, B.; Gupta, A. Recent trends in intelligent transportation systems: A review. J. Transp. Lit. 2015, 9, 30-34. [CrossRef]

14. Cobo, M.J.; Chiclana, F.; Collop, A.; de Ona, J.; Herrera-Viedma, E. A Bibliometric Analysis of the Intelligent Transportation Systems Research Based on Science Mapping. IEEE Trans. Intell. Transp. Syst. 2014, 15, 901-908. [CrossRef]

15. Cohen-Blankshtain, G.; Rotem-Mindali, O. Key research themes on ICT and sustainable urban mobility. Int. J. Sustain. Transp. 2016, 10, 9-17. [CrossRef]

16. Maimaris, A.; Papageorgiou, G. A review of intelligent transportation systems from a communications technology perspective. In Proceedings of the 2016 IEEE 19th International Conference on Intelligent Transportation Systems (ITSC), Rio de Janeiro, Brazil, 1-4 November 2016; pp. 54-59.

17. Cobo, M.J.; Lopez-Herrera, A.G.; Herrera, F.; Herrera-Viedma, E. A Note on the ITS Topic Evolution in the Period 2000-2009 at T-ITS. IEEE Trans. Intell. Transp. Syst. 2012, 13, 413-420. [CrossRef]

18. Xu, X.; Liu, Y.; Wang, W.; Zhao, X.; Sheng, Q.Z.; Wang, Z.; Shi, B. ITS-Frame: A Framework for Multi-Aspect Analysis in the Field of Intelligent Transportation Systems. IEEE Trans. Intell. Transp. Syst. 2018, 20, 2893-2902. [CrossRef]

19. Moral-Munoz, J.A.; Cobo, M.J.; Chiclana, F.; Collop, A.; Herrera-Viedma, E. Analyzing Highly Cited Papers in Intelligent Transportation Systems. IEEE Trans. Intell. Transp. Syst. 2016, 17, 993-1001. [CrossRef]

20. Tang, S.H.; Li, Z.X.; Chen, D.W.; Chen, Z.M.; Liu, W.L.; Liu, X.M.; Li, L.X.; Shi, X.B. Theme Classification and Analysis of Core Articles Published in IEEE Transactions on Intelligent Transportation Systems from 2010 to 2013. IEEE Trans. Intell. Transp. Syst. 2014, 15, 2710-2719. [CrossRef]

21. Xu, X.; Wang, W.; Liu, Y.; Zhao, X.; Xu, Z.; Zhou, H. A Bibliographic Analysis and Collaboration Patterns of IEEE transactions on intelligent transportation systems Between 2000 and 2015. IEEE Trans. Intell. Transp. Syst. 2016, 17, 2238-2247. [CrossRef]

22. Zhang, Q.; Feng, Z.; Li, X.; Zheng, X.; Zhang, L. 25 Years of collaborations in IEEE intelligent systems. IEEE Intell. Syst. 2010, 25, 67-75. [CrossRef] 
23. Li, L.J.; Li, X.; Cheng, C.J.; Chen, C.; Ke, G.Y.; Zeng, D.D.; Scherer, W.T. Research Collaboration and ITS Topic Evolution: 10 Years at T-ITS. IEEE Trans. Intell. Transp. Syst. 2010, 11, 517-523. [CrossRef]

24. Sun, L.; Rahwan, I. Coauthorship network in transportation research. Transp. Res. Part A Policy Pr. 2017, 100, 135-151. [CrossRef]

25. Modak, N.M.; Merigó, J.M.; Weber, R.; Manzor, F.; de Dios Ortúzar, J. Fifty years of Transportation Research journals: A bibliometric overview. Transp. Res. Part A Policy Pr. 2019, 120, 188-223. [CrossRef]

26. Tomaszewska, E.J.; Florea, A. Urban smart mobility in the scientific literature-Bibliometric analysis. Eng. Manag. Prod. Serv. 2018, 10, 41-56. [CrossRef]

27. Gamboa-Rosales, N.K.; Ayastuy-Arizti, J.L.; Gamboa-Rosales, H.; Galván-Tejada, C.E.; Luna-García, H.; Galván-Tejada, J.I.; Celaya-Padilla, J.M.; Otegi-Olaso, J.R.; López-Robles, J.R. Past, current and future of fuel cell technologies: A bibliometric analysis of the research published during the 1968-2018 period. In Proceedings of the VII Symposium on Hydrogen, Fuel Cells and Advanced Batteries (HYCELTEC 2019), Barcelona, Spain, 1-3 July 2019; pp. 131-133.

28. Gamboa-Rosales, N.K.; Ayastuy-Arizti, J.L.; Otegi-Olaso, J.R.; López-Robles, J.R. Research overview of hydrogen production from biomass: A bibliometric analysis of the research published during the 1979-2019 period. In Proceedings of the VII Symposium on Hydrogen, Fuel Cells and Advanced Batteries (HYCELTEC 2019), Barcelona, Spain, 1-3 July 2019; pp. 172-174.

29. González-Benito, J.; Lannelongue, G.; Alfaro-Tanco, J.A. Study of supply-chain management in the automotive industry: A bibliometric analysis. Int. J. Prod. Res. 2013, 51, 3849-3863. [CrossRef]

30. Moed, H.F. New developments in the use of citation analysis in research evaluation. Arch. Immunol. Et Ther. Exp. 2009, 57, 13. [CrossRef] [PubMed]

31. Glenisson, P.; Glänzel, W.; Janssens, F.; De-Moor, B. Combining full text and bibliometric information in mapping scientific disciplines. Inf. Process. Manag. 2005, 41, 1548-1572. [CrossRef]

32. Alonso, S.; Cabrerizo, F.J.; Herrera-Viedma, E.; Herrera, F. h-Index: A review focused in its variants, computation and standardization for different scientific fields. J. Informetr. 2009, 3, 273-289. [CrossRef]

33. Schubert, A. Successive h-indices. Scientometrics 2007, 70, 201-205. [CrossRef]

34. Martínez, M.A.; Herrera, M.; López-Gijón, J.; Herrera-Viedma, E. H-Classics: Characterizing the concept of citation classics through H-index. Scientometrics 2014, 98, 1971-1983. [CrossRef]

35. Hirsch, J.E. An index to quantify an individual's scientific research output. Proc. Natl. Acad. Sci. USA 2005, 102, 16569-16572. [CrossRef]

36. López-Robles, J.R.; Cobo, M.J.; Gamboa-Rosales, N.K.; Herrera-Viedma, E. Mapping the Intellectual Structure of the International Journal of Computers Communications and Control: A Content Analysis from 2015 to 2019. In Proceedings of the International Conference on Computers Communications and Control; Oradea, Romania, 11-15 May 2020; pp. 296-303.

37. Herrera-Viedma, E.; López-Robles, J.-R.; Guallar, J.; Cobo, M.-J. Global trends in coronavirus research at the time of Covid-19: A general bibliometric approach and content analysis using SciMAT. El Prof. De La Inf. 2020, 29, 11. [CrossRef]

38. López-Robles, J.R.; Rodríguez-Salvador, M.; Gamboa-Rosales, N.K.; Ramirez-Rosales, S.; Cobo, M.J. The last five years of Big Data Research in Economics, Econometrics and Finance: Identification and conceptual analysis. Procedia Comput. Sci. 2019, 162, 729-736. [CrossRef]

39. López-Robles, J.R.; Otegi-Olaso, J.R.; Porto-Gómez, I.; Gamboa-Rosales, H.; Gamboa-Rosales, N.K. La relación entre Inteligencia de Negocio e Inteligencia Competitiva: Un análisis retrospectivo y bibliométrico de la literatura de 1959 a 2017. Rev. Esp. Doc. Cient. 2020, 43, e256. [CrossRef]

40. López-Robles, J.R.; Otegi-Olaso, J.R.; Porto-Gomez, I.; Gamboa-Rosales, H.; Gamboa-Rosales, N.K. Understanding the intellectual structure and evolution of Competitive Intelligence: A bibliometric analysis from 1984 to 2017. Technol. Anal. Strat. Manag. 2020, 32, 604-619. [CrossRef]

41. He, Q. Knowledge discovery through co-word analysis. Libr. Trends 1999, 48, 133-159.

42. Sternitzke, C.; Bergmann, I. Similarity measures for document mapping: A comparative study on the level of an individual scientist. Scientometrics 2009, 78, 113-130. [CrossRef]

43. Cobo, M.J.; Lopez-Herrera, A.G.; Herrera-Viedma, E.; Herrera, F. SciMAT: A new science mapping analysis software tool. J. Am. Soc. Inf. Sci. Technol. 2012, 63, 1609-1630. [CrossRef]

44. López-Robles, J.R.; Otegi-Olaso, J.R.; Porto-Gómez, I.; Cobo, M.J. 30 years of intelligence models in management and business: A bibliometric review. Int. J. Inf. Manag. 2019, 48, 22-38. [CrossRef] 
45. Cobo, M.J.; López-Herrera, A.G.; Herrera-Viedma, E.; Herrera, F. An approach for detecting, quantifying, and visualizing the evolution of a research field: A practical application to the Fuzzy Sets Theory field. J. Informetr. 2011, 5, 146-166. [CrossRef]

46. Moral-Muñoz, J.A.; Herrera-Viedma, E.; Santisteban-Espejo, A.; Cobo, M.J. Software tools for conducting bibliometric analysis in science: An up-to-date review. El Prof. De La Inf. 2020, 29. [CrossRef]

47. Glänzel, W. Bibliometric Mehtods for Detecting and Analysing Emerging Research Topics. Prof. Inf. 2012, 21, 194-201. [CrossRef]

48. Wang, J. Citation time window choice for research impact evaluation. Scientometrics 2013, 94, 851-872. [CrossRef]

49. Callon, M.; Courtial, J.P.; Laville, F. Co-Word Analysis as a Tool for Describing the Network of Interactions between Basic and Technological Research-The Case of Polymer Chemistry. Scientometrics 1991, 22, 155-205. [CrossRef]

Publisher's Note: MDPI stays neutral with regard to jurisdictional claims in published maps and institutional affiliations.

(C) 2020 by the authors. Licensee MDPI, Basel, Switzerland. This article is an open access article distributed under the terms and conditions of the Creative Commons Attribution (CC BY) license (http://creativecommons.org/licenses/by/4.0/). 